\title{
On the Post-Ubaid stratigraphy and complex architecture of the Birecik Dam Area (Turkish Euphrates): Surtepe and Tilbes-Körche Late Chalcolithic 1 levels
}

\author{
Estratigrafía Post-Ubaid y arquitectura compleja \\ en el pantano de Birecik (Éufrates turco): niveles \\ del Calcolítico Final 1 en Surtepe y Tilbes-Körche
}

\author{
JESÚS GIL FUENSANTA \\ LA SEI-ICFS (Instituto de Ciencias Forenses) \\ Universidad Autónoma de Madrid \\ Campus de Cantoblanco, 28049 Madrid \\ Eurasia.icfs@uam.es \\ https://orcid.org/0000-0002-6455-4470
}

\author{
ALFREDO MEDEROS MARTíN \\ Dpto. de Prehistoria y Arqueología \\ Facultad de Filosofía y Letras \\ Universidad Autónoma de Madrid \\ Campus de Cantoblanco, 28049 Madrid \\ alfredo.mederos@uam.es \\ https://orcid.org/0000-0002-0036-7940
}

\author{
OTABEK UKTAMOVICH MUMINOV \\ Facultad de Historia \\ Universidad Nacional Mirzo Ulug Beg \\ Tashkent, Uzbekistán \\ otabekmuminov@gmail.com
}

\begin{abstract}
During the Later Prehistory of the Euphrates and Tigris Rivers and adjacent regions, a great cultural spread took place during the Late/Terminal Ubaid phases of Southern Mesopotamia. In the Northern Mesopotamian regions, it happened during the immediate pre-Late Chalcolithic phases. Excavations in Southeastern Turkey prove a continuity of Ubaid cultural traits at least during the earlier phases of the local Late Chalcolithic (LC1). Two archaeological sites, Surtepe and Tilbes-Körche, close to the Birecik Dam area (Turkish Euphrates) are presented and evaluated here. Surtepe höyük, a 8 ha Late Ubaid settlement that provided Coba bowls, has levels with painted pottery from the late Late Chalcolithic 1 or earlier LC2 phases in an area of at least 4 hectares in south and southwestern slopes.

The small site of Tilbes-Körche has probably a bigger inter-connected structure and no simple isolated buildings. Among the stone foundations we identify at least one tripartite premise with a surface over $90 \mathrm{~m} 2$ and two bipartite buildings. From the largest excavated unit $\left(\mathrm{H}_{3}-\mathrm{H}_{1} \mathrm{O}\right)$ was recovered a stamp seal depicting a crosshatching motif and another token/stamp seal with 8 incised lines. Within LC1 or a transitional phase between it and LC2, the $18 \%$ of the pottery found in the Tilbes-Körche buildings was painted and there is a huge abundance of unpainted bowls, which are about half the ceramic ensemble, many with traces of a wheel or slow-wheel, mass-produced bowls, various variants of LC1 flint scraped, and two bowls that most resemble the so-called "flower pots".
\end{abstract}

Key words: Late Chalcolithic, Halaf, Ubaid, Post-Ubaid, Mesopotamia, Birecik Dam, Project Tilbes Höyük, Surtepe

\section{Resumen}

Durante la prehistoria reciente de los ríos Éufrates y Tigris y regiones adyacentes, una gran expansión cultural tuvo lugar durante las fases tardías y terminales de Ubaid del sur de Mesopotamia. En las regiones del norte de Mesopotamia, aconteció durante las fases previas del Calcolítico Final. Excavaciones en partes del sureste de Turquía demuestran la continuidad de los rasgos culturales Ubaid, al menos durante las fases más tempranas del Calcolítico Final 1 (LC1) local. Aquí se presentan y evalúan algunos sitios arqueológicos, Tilbes Höyük, Tilbes-Körche y Surtepe, cerca del área de la presa Birecik (Éufrates turco). Surtepe höyük, un asentamiento de 8 ha del Ubaid Final que proporcionó cuencos tipo Coba, tiene niveles con cerámicas pintadas de la fase final del LC1 o de comienzos del LC2 en un área de al menos 4 ha en las laderas sur y suroeste.

El pequeño asentamiento de Tilbes-Körche tiene probablemente una gran estructura interconectada y no simples edificios aislados. Entre los cimientos de piedra identificamos al menos uno tripartito con una superficie de más de $90 \mathrm{~m}^{2}$ y dos edificios bipartitos. En la unidad excavada más grande $\left(\mathrm{H}_{3}-\mathrm{H}_{1} \mathrm{O}\right)$ se recuperó un sello que representa un motivo de rayado cruzado y otro sello o token con ocho líneas incisas. Dentro del LC1 o 
una fase de transición con LC2, el 18 \% de la cerámica encontrada en los edificios de Tilbes-Körche fue pintada y hay una gran abundancia de cuencos sin pintar, que son aproximadamente la mitad del conjunto cerámico, muchos con restos de torno lento, producidos en masa, varias variantes de cuencos raspados por sílex del LC1, y dos cuencos que se parecen más a las llamadas «macetas de flores».

Palabras clave: Calcolítico Final, Halaf, Ubaid, Post-Ubaid, Mesopotamia, pantano de Birecik, Proyecto Tilbes Höyük, Surtepe

\section{Резюме}

Во время недавней предыстории рек Евфрат и Тигр и прилегающих районов большое культурное распространение имело место во время поздних / завершающих фаз убейда в южной Месопотамии. В северных районах Месопотамии это произошло во время ближайших фраз позднего халколита. Недавние раскопки в некоторых частях юго-восточной Турции демонстрируют преемственность убайдских культурных особенностей, по крайней мере, на ранних этапах местного позднего халколита (LC1). Здесь представлены и оценены некоторые археологические памятники, Тильбес Хоюк, Тилбес-Корче и Суртепе, вблизи области плотины Биречик (Турецкий Евфрат).

Суртепе Хойюк, 8-га поселение позднего Убейда, который обеспечил бассейны Коба, имеет уровни с расписной керамикой из поздней позднекололитовой фазы 1 или раннего ЛК 2 на площади не менее 4 га на южных и юго-западных склонах, Небольшое поселение Тильбес-Кёрче, вероятно, имеет более крупную взаимосвязанную структуру, а не просто изолированные здания. Среди каменных фундаментов мы выделяем как минимум одно трехстороннее помещение площадью более 90 м2 и два двухсторонних здания. Из самого большого раскопанного блока (Н3-Н10) была найдена печать с изображением поперечной штриховки и другая печать с 8 надрезанными линиями. В пределах LC1 или переходной фазы между ним и LC2 18\% керамики, найденной в зданиях Tilbes-Körche, было окрашено, и существует большое количество неокрашенных чаш, которые составляют около половины керамического ансамбля, многие с остатками колеса или медленного колеса, несколько вариантов чаш, очищенных с помощью flix LC1 или произведенных в массе, и две, которые больше похожи на так называемые «цветочные горшки».

Ключевые Слова: поздний халколит. Убейд Постубайд. Халаф Северная и Южная Месопотамия. Биреджик. Проект Тильбес Хойюк. Суртепе

1. Introduction: The "post-Ubaid" and the Middle-Upper Tigris and Euphrates Late Chalcolithic

In this paper, we focus on the materials from certain portions of the Middle Turkish Euphrates. The Late Ubaid and post-Ubaid (earlier Late Chalcolithic or LC1) question and Northern Mesopotamia have some main questions concerning this study about the Birecik Dam area of Southeastern Turkey. As Stein (2012: 132) emphasizes: "At present, the LC1 period is the largest lacuna in our understanding of the developmental sequence of social complexity in Upper Mesopotamia”.

Ubaid was a critical culture for the development of the first pre-urban elements in Mesopotamia. During the long period that culture appeared and developed in southern Mesopotamia, the first Calcolithic settlements were transformed into large towns with complex social and economic structures, laying the foundations for the development of the first eminent urban culture of Mesopotamia, Uruk. Thus, the time of Ubaid is a key phase in the end of Prehistory of Western Asia, where a transition between the "big villages" on a complex scale and the first cities is noticed. The last phases of the "Ubaid expansion" offer elements in architecture that were interpreted decades ago as typical of the Uruk culture.

During the Later prehistory of the Euphrates and Tigris rivers and adjacent regions, a great cultural spread reached even as far away as the Gulf Area or Turkish Cilicia and occurred mainly during the Ubaid 3-4 phases of southern Mesopotamia. The presence of the Ubaid culture in the north is only considered from the Ubaid 3 phase of southern Mesopotamia, and it appears on the previous roots 


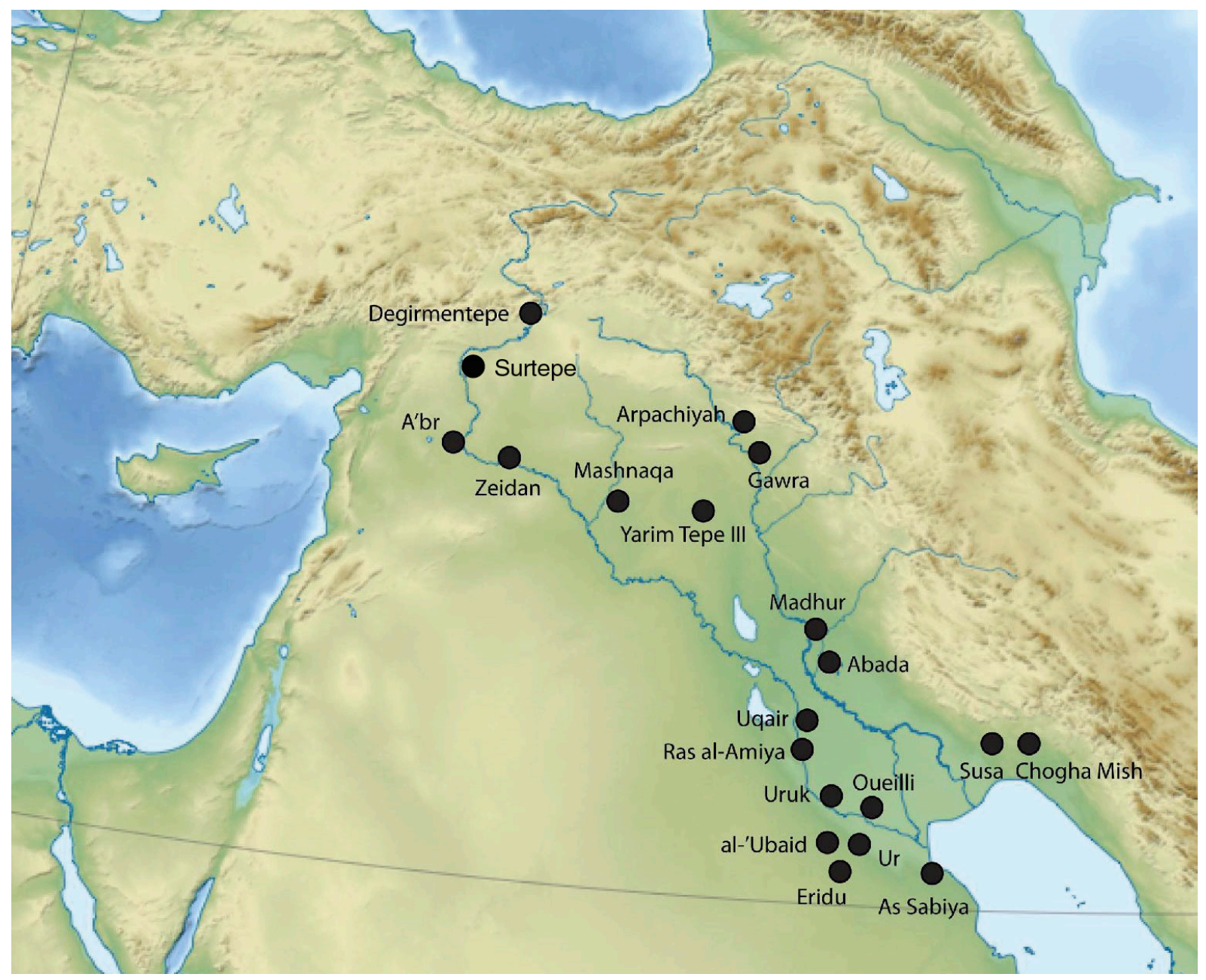

Figure 1. Surtepe in Ubaid and 'Ubaid-related sites in $6^{\text {th }}-5^{\text {th }}$ millennium BC Mesopotamia and neighboring regions (based on Stein, 2014: 64 fig. 1)

Figura 1. Surtepe y otros asentamientos de la fase Ubaid durante el VI y V milenios a. C. en Mesopotamia y las regiones vecinas (a partir de Stein, 2014: 64 fig. 1)

of the Halaf culture. There are many previous centuries when the South experienced the Ubaid culture but did not occur in the North (figure I).

There is some belief that there is an apparent break in northern Mesopotamia from the Ubaid tradition from Halaf (Carter and Philip, 2010: 4). However, there are several researchers who demonstrate the gradual transition between the two cultures at least in certain territories in northern $\mathrm{Me}$ sopotamia, such as the Khabur River. Tell Aqab is proof of that type of Halaf-Ubaid transition (Mühl and Nieuwenhuyse, 20I6). Tell Kosak Shamali in the Middle Euphrates demonstrates the existence of Halaf and Ubaid cultural contact in its ceramic production (Nishiaki and Matsutani, 2003; Campbell and Fletcher, 20IO).
The first matter concerns about the potentiality or rejection of the Halaf culture as a forerunner for Ubaid. When both cultures occur in a same place (in general, at many big sites of the Northern Euphrates regions) the Ubaidian-like levels overlay directly on the final horizons of the Halaf culture. In correspondence, sites from Northern Syria, such as Tell Leilan, also show continuity and gradual changes (Schwartz, I988).

But in the Sajour area, nearby the Syrian Tishrin Dam, is not distinguished a transitional Halaf to the Ubaid culture (Sanlaiville, I985: 103). The Tishrin Dam sites yield data about a transitional Halaf to the Ubaid consistent with the materials from most of the adjacent areas (Hammade and Yamazaki, 1993). A similar issue was stressed 
for the regional "Southern Ubaid" paint and fabric and there the Samarra culture looks as a most likely cultural ancestor (Blackman, 1996). The facts point to a major Halaf influence just on certain regions and whom degree of predominance depends of the local characters.

With Ubaid we are facing an expansionist culture, although the character of this expansion may well have changed over time. Perhaps in the first instance it was commercial or cultural, at least in some territories of Mesopotamia. The first evidence of possible conflicts between Ubaid and Halaf cultures appears in the Cilicia area, at a time parallel to the Ubaid 3 phase of southern Mesopotamia (Breniquet, 1995). But there is no evidence of widespread violence in the Ubaid orb, until the end of phase Ubaid 4. But we insist that the previous replacement of Halaf by Ubaid does seem violent in various northern regions, such as the case of Cilicia. On the other hand, certain practices (elongated skulls) could speak in favor of ethnic or social segregation (Croucher, 20IO: II8), and not at all of the so-called "primitive democracy" for Ubaid that was presumed among a few researchers in the middle of the 2oth century. Late Ubaid it was not an egalitarian society.

With the post-Ubaid, that is to say, that period after the Late Ubaid and before the great expansion of the Uruk culture in its Middle phase, at the beginning of this century scholars recognised this period in the North, so-called Late Chalcolithic (LC) I-2, (after Santa Fe Chronological charts, Rothman 20or: 7 table I.I, 9 table I.2) as a phase parallel to the Early Uruk of Southern Mesopotamia. Just earlier several authors spoke of an "Uruk post-Northern Ubaid" (Henrickson and Thuesen, I988). Post-Ubaid is a phenomenon that on the archaeological level did not begin to be elucidated until the first years of the $2 \mathrm{I}^{\mathrm{st}}$ century. Excavated levels were scarce. In the northern regions of Mesopotamia, the phenomenon took place during the earlier phase of the Late Chalcolithic (LC1).

In general terms, post-Ubaid is a period that in chronological terms covers the final centuries of the $5^{\text {th }}$ Millennium BC. The final moment of the Late Ubaid and the beginning of the Late Chalcolithic, which comes within the post-Ubaid chronological consideration, is a fuzzy epoch both in its archaeological interpretation and in the recognition of several of its characteristics. The calibrated dates for the earliest $\mathrm{LC} 1$, range from $4600-4200 \mathrm{BC}$ from Tell Zeidan in the Balikh (Stein, I999, 2009, 2010) and suggest an existence of several centuries for this phase so distorted in the archaeological plane (figure 2a; table I).

To date, just a very few data about the post-Ubaidlike culture were recovered for the archaeological stratigraphy of the Northern Euphrates region. Tepe Gawra, due to its stratigraphic continuity from the beginnings of Halaf until the III millennium BC, remains the great reference stratigraphy. In the last thirty years, new stratigraphies have emerged that serve as a regional reference for one or more phases of the Late Chalcolithic of the North, but we still do not have a similar "Gawra" chronological site. However, there are regional reference stratigraphic sequences that are supported, on many occasions, by soundings, limited exposure in extension or surveying. Sometimes they are difficult to square completely with the sequence of another place of the period in a different region. In the main course of the Middle Euphrates we have scarce evidence, such as Tell Kosak Shamali levels 6-5 in sector B (Nishiaki and Matsutani, 2003). In the Balikh we have clearer sequences between Late Ubaid and LC3 such as Tell Hammam et-Turkmann (Akkermans, I988) or recently Tell Zeidan (Stein, 2009; Fisher, 20I7). On the other main subsidiary of the Euphrates, the Khabur, we count on several sequences for the LC phases, such as Tell Feres al Sharqi (Baldi, 20I2), Tell Leilan VI (Schwartz, 1988; Brustolon and Rova, 2007), Tell Brak (Oates, 2012) and Tell Hamoukar Level IV (Jayyab, 20I2). For other North Mesopotamian sub-regions some come from surveying or burial contexts as it was at Tell Kashkashok II (Matsutani, 199I). We also see similar LC places in the Tigris region, such as Helawa (Erbil Plain) (Peyronel et al., 20I6). However, there are other places in the Tigris river, as the case of Kenan Tepe, whose Ubaid occupation would end in the local Terminal Ubaid period, dated around $4300 \mathrm{BC}$, and they do not present what we understand as LC1-2 Post-Ubaid occupation of the Euphrates (Parker and Kennedy, 2010) (figure 2b). 
Figure 2. A. Late Ubaid and Late Chalcolithic 1-2 Chronology in the Middle Euphrates. OxCal 4.3.2. B. Late Ubaid and Late Chalcolithic 1-2 sequences in Mesopotamia (Fisher, 2017: 45 table 2)

Figura 2. A. Cronología del Ubaid Final y Calcolítico Final 1-2 en el Éufrates Medio. OxCal 4.3.2. B. Secuencias del Ubaid Final y Calcolítico Final 1-2 en Mesopotamia (Fisher, 2017: 45 tabla 2)

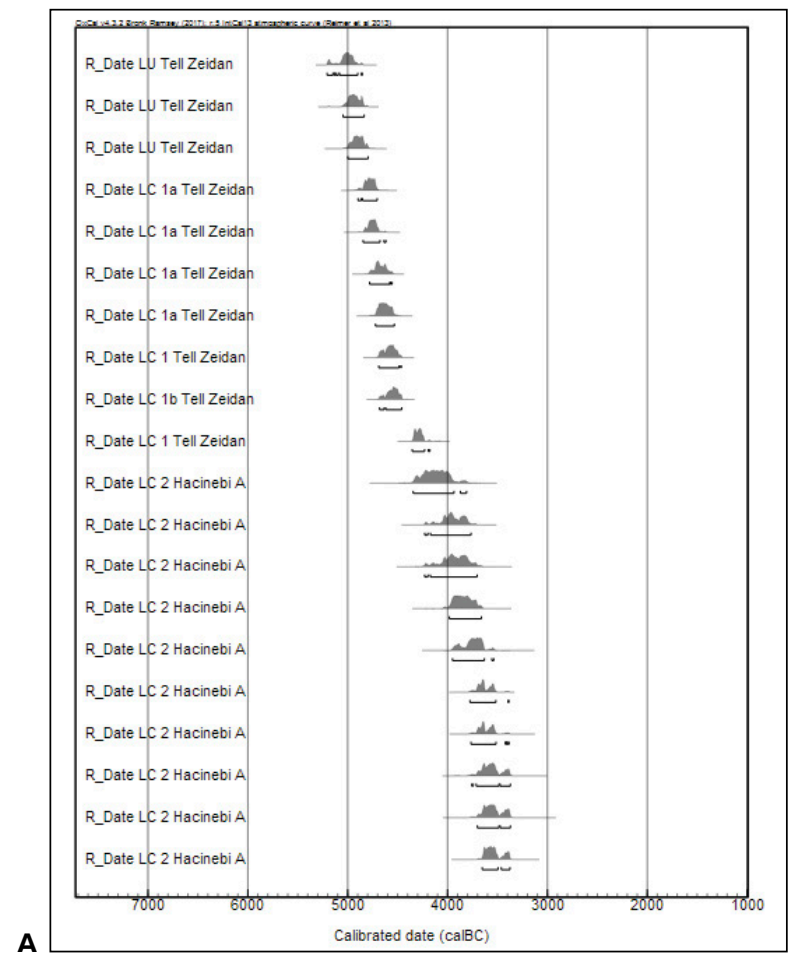

B

\begin{tabular}{|c|c|c|c|c|c|c|c|c|c|c|c|c|c|c|}
\hline BC Cal. & Period & Tell Zeidan & Cilicia & $\begin{array}{l}\text { Amuq \& } \\
\text { Orontes }\end{array}$ & $\begin{array}{l}\text { Queiq } \\
\text { Region }\end{array}$ & $\begin{array}{l}\text { Middle } \\
\text { Euphrates }\end{array}$ & $\begin{array}{l}\text { Balikh } \\
\text { Valley }\end{array}$ & Upper Euphrates & Middle Khabur & Upper Khabur & Tigris & Erbil Plain & $\begin{array}{l}\text { Caucuses \& } \\
\text { Western Iran }\end{array}$ & \begin{tabular}{|l|} 
Southern \\
Mesopotamia
\end{tabular} \\
\hline 3850 & & & & & & & & & & Brak TW 23 & & Qalinj Agha III & & \\
\hline 4000 & LC 2 & LC $2 b$ & & $\left.{ }_{H}^{A m u m a} K^{2}\right\rangle-1$ & $\begin{array}{l}\text { Coba Höyük } \\
\text { IVC; } \\
\text { Oylum Höyük }\end{array}$ & & Hommom UR & $\begin{array}{l}\text { Hacmebi Phase A; } \\
\text { Arslantepe VIII }\end{array}$ & & $\begin{array}{l}\text { Hamoukar } \\
\text { Level } 2\end{array}$ & Gawra XA - IX & & $\begin{array}{l}\text { Ovçular Tepesi } \\
\text { Phase II; }\end{array}$ & \begin{tabular}{|l} 
Early Unuk; \\
Eanna XII
\end{tabular} \\
\hline 4100 & & LC 2a & \begin{tabular}{|l|} 
Yüminktepe \\
XIII \\
Gözlü Kule LC
\end{tabular} & & & & & $\begin{array}{l}\text { Korucutuepe } \\
\text { Early Phase B } \\
\text { Norswutepe }\end{array}$ & & $\begin{array}{l}\text { Brak CH 19; } \\
\text { HS6 Level 6; } \\
\text { Feres Level } 6\end{array}$ & $\begin{array}{l}\text { Ninveh III L:62 } \\
\text { Yenice Yani }\end{array}$ & Qalinj Agha IV & $\begin{array}{l}\text { Acropole 22-19; } \\
\text { Godin Late VII }\end{array}$ & Eanna XIII \\
\hline & & & & & & & & Phase II Level 10 & & $\begin{array}{l}\text { Hamounkar } \\
\text { Level } 3\end{array}$ & $\begin{array}{l}\text { Yence } \\
\text { YY4 }\end{array}$ & Surezha LC2 & & $\begin{array}{l}\text { Enidu Temple } \\
\text { Sounding V }\end{array}$ \\
\hline 4200 & & LC 1.2 & & $\begin{array}{l}\text { Tell es-Sheikh } \\
\text { II-I }\end{array}$ & & & $\begin{array}{l}\text { Hammam VA } \\
\text { Strata 3-4 }\end{array}$ & & \begin{tabular}{|l|} 
Ziyadeh Phase III \\
Levels 15-16
\end{tabular} & Hamoukar & Gawra XIA/B & & $\begin{array}{l}\text { Ovcular Tepesi } \\
\text { Phase I; } \\
\text { Godin Early VII }\end{array}$ & Eanna XIV \\
\hline 4300 & LC 1 & LC Id & $\begin{array}{l}\text { Yümükttepe } \\
\text { XV }\end{array}$ & $\begin{array}{l}\text { Ras Shamra } \\
\text { III B h-f; } \\
\text { Hama K10-8 } \\
\text { Abd al-Aziz } \\
\text { 4-1; }\end{array}$ & $\begin{array}{l}\text { Coba Hōyük } \\
\text { IVB; } \\
\text { Oylum Höyük }\end{array}$ & \begin{tabular}{|l|} 
Tell al-'Abr \\
Stage IV \\
Kosak Shamali \\
Sector B Lv. 5 \\
\end{tabular} & $\begin{array}{l}\text { Hammam VA } \\
\text { Strata 1-2b }\end{array}$ & $\begin{array}{l}\text { Norsyumtepe } \\
\text { Phase II Level } 11 \\
\text { Arslantepe VIII }\end{array}$ & $\begin{array}{l}\text { Umm Qseir } \\
\text { Phase 2 }\end{array}$ & $\begin{array}{l}\text { Level 4 } \\
\text { Tell Feres 7; } \\
\text { Brak CH 20; } \\
\text { HS6 9-8; } \\
\text { Leilan VIb, }\end{array}$ & $\begin{array}{l}\text { Yenice Yani } \\
\text { Later YY5 }\end{array}$ & Qalinj Agha V & $\begin{array}{l}\text { Terminal Susa A } \\
\text { Acropole 24-23; } \\
\text { Susa Necropole; } \\
\text { Later Pisdeli Phase }\end{array}$ & Eanna XV \\
\hline & & LC $1 \mathrm{c}$ & & $\begin{array}{l}\text { Arjoune Trench } \\
\text { VI; } \\
\text { Telles-Sheikh }\end{array}$ & & $\begin{array}{l}\text { elll al-Abr } \\
\text { Stage III-2 }\end{array}$ & Hammam IVD & lower level & Ziyad & Stratum 52a & Gawra XII & & \begin{tabular}{|l} 
Kül Tepe Level VII; \\
Hasanlu Level VII
\end{tabular} & $\begin{array}{l}\text { Eridu Temple } \\
\text { Sounding VI }\end{array}$ \\
\hline 4500 & & LC $1 b$ & & & & \begin{tabular}{|l|} 
Tell al ' $'$ 'Abr \\
Stage III-1
\end{tabular} & Strata $11-12$ & $\begin{array}{l}\text { Norsumtepe } \\
\text { Phase IC }\end{array}$ & Level & Feres Level 8 & \begin{tabular}{|l} 
Kenan Tepe \\
Ubaid Phase 4
\end{tabular} & Qalinj Agha VI & $\begin{array}{l}\text { Susa A period } \\
\text { Acropole 27-25; } \\
\text { Earlier Pisdeli; }\end{array}$ & \\
\hline 4600 & Thaid_Ic & IC la & $\begin{array}{l}\text { Yümuilktepe } \\
\text { XyI }\end{array}$ & \begin{tabular}{|l|} 
Karaça Khirbet \\
'Ali; \\
Tell es-Sheikh \\
VII-V \\
Ras Shamra
\end{tabular} & Coba Hôyiuk & $\begin{array}{l}\text { Kosak Shamali } \\
\text { Sector A Lv. 1; } \\
\text { Tell al-'Abr } \\
\text { Stage II (Iv. 5) }\end{array}$ & $\begin{array}{l}\text { Strata 9-10 } \\
\text { Hammam IVC } \\
\text { Strata 8a-c }\end{array}$ & $\begin{array}{l}\text { Değirmentepe } \\
\text { Layer } 7 \\
\text { Norşuntepe } \\
\text { Phase IA }\end{array}$ & $\begin{array}{l}\text { Ziyadeh Phase } \\
\text { III Level } 13\end{array}$ & $\begin{array}{l}\text { Feres Level 9a } \\
\text { Brak CH } 21 \\
\text { Leilan VTb, } \\
\text { Strata 57-52; }\end{array}$ & $\begin{array}{l}\text { Gawra XIIA; } \\
\text { Ninveh II L:60; } \\
\text { Yenice Yani } \\
\text { Earlier YY5 }\end{array}$ & Surezha LC 1 & $\begin{array}{l}\text { Godin VIII } \\
\text { Seh Gabi Phase }\end{array}$ & $\begin{array}{l}\text { Eanna XVI } \\
\text { Eridu Temple } \\
\text { Sounding VII }\end{array}$ \\
\hline 4800 & Ubard-LC & Uband-LC 1 & & $\begin{array}{l}\text { II B B i } \\
\text { Late Amuq E; } \\
\text { Hama L2.1 }\end{array}$ & & $\begin{array}{l}\text { Kosal Shamali } \\
\text { Sector B Lv. } 6\end{array}$ & $\begin{array}{l}\text { Hammam IVC } \\
\text { Stratum } 7\end{array}$ & $\begin{array}{l}\text { Degirmentepe } \\
\text { Layer } 8\end{array}$ & & Feres Level $9 \mathrm{~b}$ & Gawra XIII & Qalinj Agha VII & $\begin{array}{l}\text { End of Dalma } \\
\text { Phase; Godin IX }\end{array}$ & \\
\hline
\end{tabular}

Other important problem regards the uncertainty of setting a Post-Ubaid period. In the Northern Syrian region, we see several patterns. For the Khabur, there is no break between the Late Ubaid and Uruk cultures (vgr. Tell Brak, Oates, I994: I73). But in the Balikh river area, the local Late Chalcolithic outgrowth, come gradually after the Ubaid-like levels (cf. Tell Hammam et-Turkmann, Akkermans, I988). Similar local cultural developments could be interpreted after the Orontes River area materials and the adjacent regional sequences (de Contenson, I963: 38-39; 1982: 96; Copeland, 1979: 270 ff.).
The Late Chalcolithic (LC) 1 period of northern Mesopotamia in current chronology (Rothman, 200I) largely coincides with was previously known as Terminal Ubaid (Oates, 1976; Forest, 1996). The Terminal Northern Ubaid phase, called Ubaid 5 if we follow the sequence of Ubaid o-4, with which the Ubaid period was designated in the chronological sequences of the late twentieth century, corresponds to the beginning of the Late Chalcolithic sequence, that is, LC1, what we call post-Ubaid, especially in the archaeological investigation of the present century. Recent considerations of the calibrated chronology 


\begin{tabular}{|c|c|c|c|c|c|c|c|c|}
\hline Site & $\begin{array}{c}\text { Municipality, } \\
\text { Province, Region, } \\
\text { Country }\end{array}$ & BP & \pm & BC & $\begin{array}{l}\max . \\
\text { CAL } \\
(2 \delta)\end{array}$ & $\begin{array}{c}\text { med. } \\
\text { CAL } \\
\text { BC }\end{array}$ & $\begin{array}{l}\min . \\
\text { CAL } \\
(2 \delta)\end{array}$ & Lab. $n^{\circ}$ \& Sample \\
\hline $\begin{array}{l}\text { Late Ubaid, Tell Zeidan, operation 1, locus } 16 \text {, } \\
\text { beneath wall } 16\end{array}$ & Raqqa, Syria & 6090 & 40 & 4140 & $\begin{array}{l}5207 \\
5206\end{array}$ & $\begin{array}{l}4994 \\
4965\end{array}$ & $\begin{array}{l}4849 \\
4849\end{array}$ & Beta-248.970 \\
\hline $\begin{array}{l}\text { Late Ubaid, Tell Zeidan, phase D, operation } 9 \text {, } \\
\text { locus 59, general room buildup }\end{array}$ & Raqqa, Syria & 6040 & 40 & 4090 & $\begin{array}{l}5044 \\
5047\end{array}$ & $\begin{array}{l}4937 \\
4869 \\
4860 \\
\end{array}$ & $\begin{array}{l}4801 \\
4798\end{array}$ & Beta-288.099 \\
\hline $\begin{array}{l}\text { Late Ubaid, Tell Zeidan, phase D, operation 9, } \\
\text { locus 59, general room buildup }\end{array}$ & Raqqa, Syria & 6010 & 40 & 4060 & $\begin{array}{l}5000 \\
4997\end{array}$ & $\begin{array}{l}4904 \\
4887 \\
4881 \\
4873 \\
4853\end{array}$ & $\begin{array}{l}4794 \\
4780\end{array}$ & Beta-288.100 \\
\hline LC 1a, Tell Zeidan, operation 3, locus 63 & Raqqa, Syria & 5910 & 40 & 3960 & $\begin{array}{l}4898 \\
4900\end{array}$ & $\begin{array}{l}4779 \\
4746 \\
4742 \\
\end{array}$ & $\begin{array}{l}4696 \\
4693\end{array}$ & Beta-248.981 \\
\hline $\begin{array}{l}\text { Very Late Ubaid-LC 1a, Tell Zeidan, phase Ilb, } \\
\text { operation } 17 \text {, locus } 25 \text {, room/floor deposit }\end{array}$ & Raqqa, Syria & 5880 & 40 & 3930 & $\begin{array}{l}4845 \\
4846\end{array}$ & $\begin{array}{l}4771 \\
4751 \\
4724 \\
\end{array}$ & $\begin{array}{l}4616 \\
4622\end{array}$ & Beta-288.112 \\
\hline $\begin{array}{l}\text { LC 1a, Tell Zeidan, operation 10, locus } 57 \text {, } \\
\text { trash pit }\end{array}$ & Raqqa, Syria & 5820 & 40 & 3870 & $\begin{array}{l}4785 \\
4783\end{array}$ & $\begin{array}{l}4707 \\
4702 \\
4692 \\
\end{array}$ & $\begin{array}{l}4550 \\
4549\end{array}$ & Beta-288.102 \\
\hline $\begin{array}{l}\text { LC 1a, Tell Zeidan, phase E, operation 15, } \\
\text { locus 97, room S.E5.3, mudbrick collapse }\end{array}$ & Raqqa, Syria & 5780 & 40 & 3830 & $\begin{array}{l}4723 \\
4770\end{array}$ & $\begin{array}{r}4671 \\
4659 \\
4651 \\
4639 \\
4618\end{array}$ & $\begin{array}{l}4505 \\
4502\end{array}$ & Beta-288.109 \\
\hline $\begin{array}{l}\text { LC1, Tell Zeidan, operation 16, locus 79, room/ } \\
\text { floor deposit }\end{array}$ & Raqqa, Syria & 5730 & 40 & 3780 & $\begin{array}{l}4687 \\
4705 \\
\end{array}$ & 4548 & $\begin{array}{l}4458 \\
4460 \\
\end{array}$ & Beta-288.111 \\
\hline $\begin{array}{l}\text { LC 1b, Tell Zeidan, phase E, operation } 3 \text {, } \\
\text { locus } 39 \text {, building S.B4 }\end{array}$ & Raqqa, Syria & 5710 & 40 & 3760 & $\begin{array}{l}4678 \\
4686 \\
\end{array}$ & 4541 & $\begin{array}{l}4453 \\
4457 \\
\end{array}$ & Beta-248.971 \\
\hline LC1, Tell Zeidan, operation 2, locus 32 & Raqqa, Syria & 5430 & 40 & 3480 & $\begin{array}{l}4354 \\
4347\end{array}$ & $\begin{array}{r}4326 \\
4281 \\
4256 \\
\end{array}$ & $\begin{array}{l}4081 \\
4165\end{array}$ & Beta-248.976 \\
\hline $\begin{array}{l}\text { LC2, Hacinebi, phase A, operation } 17 \text {, locus } 82 \text {, } \\
\text { stratum } 17 d \text {, trash deposit }\end{array}$ & $\begin{array}{l}\text { Birecik, Sanliurfa, } \\
\text { Turkey }\end{array}$ & 5280 & 110 & 3330 & $\begin{array}{l}4345 \\
4343\end{array}$ & $\begin{array}{l}4216 \\
4203 \\
4136 \\
4134 \\
4045 \\
\end{array}$ & $\begin{array}{l}3807 \\
3803\end{array}$ & Beta-88.312 \\
\hline $\begin{array}{l}\text { LC2, Hacinebi, phase A, operation 5, locus } 138 \text {, } \\
\text { trash deposit }\end{array}$ & $\begin{array}{l}\text { Birecik, Sanliurfa, } \\
\text { Turkey }\end{array}$ & 5150 & 80 & 3200 & $\begin{array}{l}4229 \\
4219 \\
\end{array}$ & 3964 & $\begin{array}{l}3714 \\
3770 \\
\end{array}$ & Beta-80.944 \\
\hline $\begin{array}{l}\text { LC2, Hacinebi, phase A, operation 12, locus } 258 \text {, } \\
\text { stratum 12g, pit fill }\end{array}$ & $\begin{array}{l}\text { Birecik, Sanliurfa, } \\
\text { Turkey }\end{array}$ & 5130 & 100 & 3180 & $\begin{array}{l}4229 \\
4221 \\
\end{array}$ & 3960 & $\begin{array}{l}3657 \\
3702 \\
\end{array}$ & Beta-113.716 \\
\hline $\begin{array}{l}\text { LC2, Hacinebi, phase A, operation } 16 \text {, } \\
\text { locus } 170 \text {, stone depot phase }\end{array}$ & $\begin{array}{l}\text { Birecik, Sanliurfa, } \\
\text { Turkey }\end{array}$ & 5050 & 80 & 3100 & $\begin{array}{l}3879 \\
4035\end{array}$ & $\begin{array}{l}3909 \\
3879 \\
3801 \\
\end{array}$ & $\begin{array}{l}3653 \\
3656\end{array}$ & Beta-113.712 \\
\hline $\begin{array}{l}\text { LC2, Hacinebi, phase A, operation 4, locus } 249 \text {, } \\
\text { stratum } 4 \text { c, roof collapse }\end{array}$ & $\begin{array}{l}\text { Birecik, Sanliurfa, } \\
\text { Turkey }\end{array}$ & 4940 & 80 & 2990 & $\begin{array}{l}3952 \\
3945 \\
\end{array}$ & 3706 & $\begin{array}{l}3534 \\
3539 \\
\end{array}$ & Beta-113.710 \\
\hline $\begin{array}{l}\text { LC2, Hacinebi, phase A, operation 14, locus } 199 \text {, } \\
\text { stratum 14g2, ash deposit in central house }\end{array}$ & $\begin{array}{l}\text { Birecik, Sanliurfa, } \\
\text { Turkey }\end{array}$ & 4850 & 60 & 2900 & $\begin{array}{l}3777 \\
3758\end{array}$ & 3644 & $\begin{array}{l}3386 \\
3521\end{array}$ & Beta-113.718 \\
\hline $\begin{array}{l}\text { LC2, Hacinebi, phase A, operation } 4 \text {, locus } 242 \text {, } \\
\text { stratum } 4 \mathrm{~d} \text {, brick collapse }\end{array}$ & $\begin{array}{l}\text { Birecik, Sanliurfa, } \\
\text { Turkey }\end{array}$ & 4840 & 60 & 2890 & $\begin{array}{l}3768 \\
3710\end{array}$ & 3643 & $\begin{array}{l}3384 \\
3518\end{array}$ & Beta-113.708 \\
\hline $\begin{array}{l}\text { LC2, Hacinebi, phase A, operation } 16 \text {, locus } 170 \text {, } \\
\text { stone depot phase floor }\end{array}$ & $\begin{array}{l}\text { Birecik, Sanliurfa, } \\
\text { Turkey }\end{array}$ & 4800 & 80 & 2850 & $\begin{array}{l}3756 \\
3710\end{array}$ & $\begin{array}{l}3636 \\
3548 \\
3544 \\
\end{array}$ & $\begin{array}{l}3371 \\
3371\end{array}$ & Beta-113.713 \\
\hline $\begin{array}{l}\text { LC2, Hacinebi, phase A, operation 4, locus } 192 \text {, } \\
\text { stratum } 4 \mathrm{~d} \text {, hearth }\end{array}$ & $\begin{array}{l}\text { Birecik, Sanliurfa, } \\
\text { Turkey }\end{array}$ & 4780 & 80 & 2830 & $\begin{array}{l}3703 \\
3706\end{array}$ & $\begin{array}{l}3632 \\
3558 \\
3540 \\
\end{array}$ & $\begin{array}{l}3370 \\
3367\end{array}$ & Beta-80.945 \\
\hline $\begin{array}{l}\text { LC2, Hacinebi, phase A, operation } 12 \text {, } \\
\text { locus } 265 \text {, stratum } 12 \mathrm{~g} \text {, smelting pit fill }\end{array}$ & $\begin{array}{l}\text { Birecik, Sanliurfa, } \\
\text { Turkey }\end{array}$ & 4770 & 60 & 2820 & $\begin{array}{l}3645 \\
3657\end{array}$ & $\begin{array}{l}3630 \\
3578 \\
3569 \\
3562 \\
3538 \\
\end{array}$ & $\begin{array}{l}3376 \\
3373\end{array}$ & Beta-113.717 \\
\hline $\begin{array}{l}\text { LC2, Hacinebi, phase A, operation } 4 \text {, } \\
\text { locus } 276 \text {, stratum } 4 \text { C, Pit with stamp seal }\end{array}$ & $\begin{array}{l}\text { Birecik, Sanliurfa, } \\
\text { Turkey }\end{array}$ & 4690 & 80 & 2740 & $\begin{array}{l}3643 \\
3644\end{array}$ & $\begin{array}{l}3503 \\
3428 \\
3381 \\
\end{array}$ & $\begin{array}{l}3136 \\
3140\end{array}$ & Beta-113.714 \\
\hline
\end{tabular}

Table 1. Late Ubaid and Late Chalcolithic 1-2 Chronology in the Middle Euphrates. Sources: Tell Zeidan (Stein, 2009: 135-136 table 1; $2010: 126$ table 1); Hacinebi A (Stein and Misir, 1995: 128 fig. 10; Stein, 1999: 194 table 1; Wright and Rupley, 2001: 106 fig. 3.16). Intcal20 calibration curve according to Reimer et al. (2020), Calib 8.1, compared to Intcal98 calibration curve, Calib v. 4.2 according to Stuiver et al. (1998), which does not smooth the peaks of the curve.

Tabla 1. Cronología del Ubaid Final y Calcolítico Final 1-2 en el Éufrates Medio. Fuentes: Tell Zeidan (Stein, 2009: 135-136 tabla 1; $2010: 126$ tabla 1); Hacinebi A (Stein y Misir, 1995: 128 fig. 10; Stein, 1999: 194 tabla 1; Wright y Rupley, 2001: 106 fig. 3.16). Curva Intcal20 de acuerdo con Reimer et alii (2020), Calib 8.1, comparada con la curva de calibración Intcal98, Calib v. 4.2 de acuerdo con Stuiver et alii (1998), que no suaviza los picos de la curva 
contemplate a subtle difference between what is considered Terminal Ubaid of Mesopotamia and LC1 of the North; according to them, LC1 would start in 4700 and end in $4200 \mathrm{BC}$, overlapping the beginning of Terminal Ubaid in other chronologies, which place it in $4600 \mathrm{BC}$ (Fisher, 2017: 386).

When the term Late Chalcolithic, of northern Mesopotamia, was used by prehistorians specialized in the area (Rothman, 200I) there were several perspectives in mind. One of them was avoiding mistakes in applying a general plan to local sequences. An important element in archaeological excavations and research on the Late Chalcolithic period is to know how to interpret and distinguish whether or not all the archaeological sites mentioned belong to the same phases of the Late Chalcolithic period, phases I-2; and find out if they cover the entire post-Ubaid time sequence in question.

There are some director fossils of LC1 in most of Northern Mesopotamia. The existence of a small percentage of painted pottery in the Northern Ubaid related tradition is one of them. The increase of the production of bowls in mass or series, derived from the Coba bowls or flint scraped bowls is another one of them; despite the fact that we tested a certain regional diversity (cf. Arslantepe VIII). Wide flower pots and the bowls with flint scraped or incision inside are typical of the $\mathrm{LC} 1$ phase.

Carinated forms begin to appear towards the end of LC1 in contexts of Khabur river (Matthews, 2003), Middle Euphrates (Hammade and Yamazaki, 2006) or Sinjar piedmont areas (Tobler, 1950). Carinated types start to appear in Tell 'Abr V (Yamazaki, 20oo); that phase seems to equal the beginning of Tell Zeidan Level LC1a, but also possibly with Zeidan Level Ubaid-LC1 (Fisher, 20I7: 379). U shaped bowls seems characteristic too of $\mathrm{LC} 1$ assemblages.

From a technological point of view, the slow wheel is more noticeable in $\mathrm{LC} 1$ than in the previous Late Ubaid (see Gawra XII,Tobler, I950: I46). And along the phase, the mineral tempered ceramics still present considerable percentages with respect to the tempered vegetable ceramics, which together with the chaff faced, will increase during the LC2 phase.

The presence of painted ceramic in $\mathrm{LC} 1$ tends to decrease with respect to Late Ubaid; but it remains at higher rates than in LC2, until it practically disappears in many regions of Mesopotamia during LC3. Among the painted motifs, some such as the "large swoops beneath the rims of bowls and the hanging $\mathrm{Xs}$ and diagonal lines of $\mathrm{X}$ patterns" are considered typical of LC1 (Fisher, 20I7: 386).

"Sprig ware" could be one of the defining elements of the late LC1-LC2; in northern Mesopotamia it is associated with early Uruk (Ball, 1997) and similar stratigraphies. Ceramic decorated with reliefs, or stamped, is a defining element that begins at the end of LC2 (Oates, 20I2: 68).

\section{The Late Chalcolithic 1-2 Levels of Surtepe Höyük}

Surtepe, on a crossing point on the Euphrates River, is the biggest mound in the Birecik area. Also it is the largest mound with a continuous sequence with Halaf, Late Chalcolithic and Early Bronze phases between Karkamış and Samsat. The site lies across the Euphrates and supposedly sits along a stretch where the river meandered, a "cul-de-sac" ideal for boats to dock had formed, as geologists believed happened at Tilbes in prehistoric times. The flora of the Surtepe area presents nowadays a fertile agriculture because of its special soil characteristics (the best of Birecik area), with variety of vegetables and trees (figures $3 a-3 b$ ).

During certain periods of the Late Antiquity, the total occupation of the Surtepe mound and its adjacent area, based on survey, sediment, and geological studies could be from up to 20 hectares, if we count the continuous surface sherd scatters. On the other hand, the levels of Later Prehistory in the different sectors of the höyük, show a long presence between Ubaid and LC in Surtepe. At least 8 hectares of Surtepe were occupied by Late Ubaid, since fragments are counted throughout the central höyük (figures $4 a-4 b)$.

According to the yielded data at Surtepe Höyük, the Uruk peoples substituted gradually the local Late Chalcolithic (with roots into the Ubaid culture). In conclusion, Surtepe must be an attractive mound since prehistoric times. The settlements pattern and 


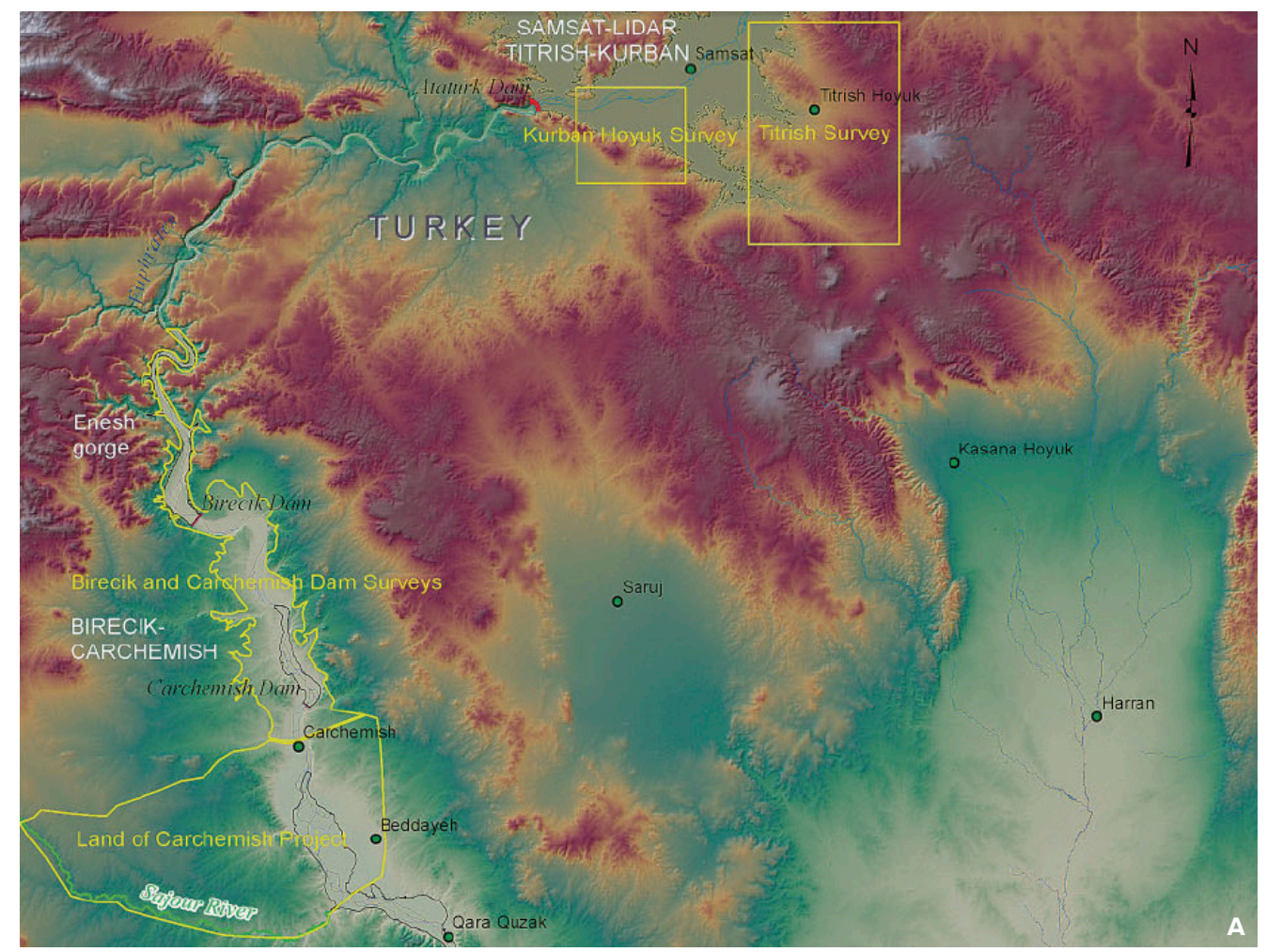

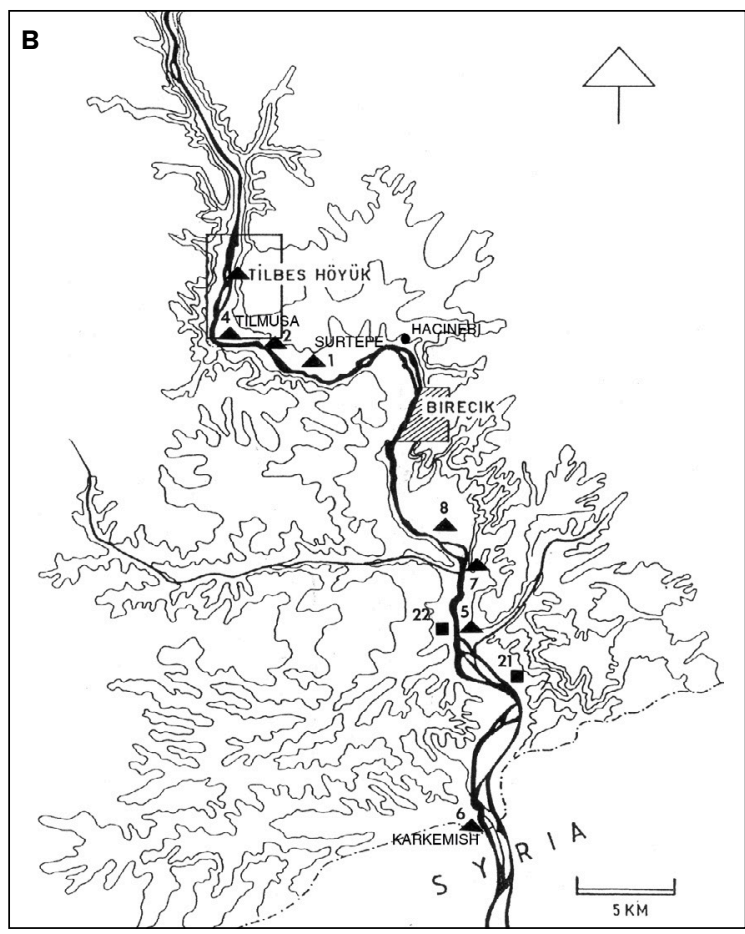

Figure 3. A. Map of the Middle Euphrates with the Birecik-Carchemish Dam surveys and major Late Chalcolithic sites (Wilkinson et al., 2012: 141, fig. 1). B. Map of the Middle Euphrates with Tilbes Höyük, Tilmusa, Surtepe and Hacinebi

Figura 3. Mapa del Éufrates Medio con las prospecciones de los pantanos de Birecik-Carchemish y principales asentamientos del Calcolítico Final (Wilkinson et alii, 2012: 141, fig. 1). B. Mapa del Éufrates Medio con Tilbes Höyük, Tilmusa, Surtepe y Hacinebi findings suggest this site as a local centre at least during the phases Late Chalcolithic 2 to 5 and the Early Bronze I-II (Kozbe and Rothman, 2005: II9, fig. 47).

At Surtepe, we started our excavations in squares where we were able to reach each of the critical Ubaid culture and Late Chalcolithic period's remains with the least over-burden of later material. This was mostly in the southern end of the mound. During the first season, we opened several soundings to determine the depth of those periods' remains. In addition, areas that were formerly eroded and dug for mudbrick by the local villagers were cleaned to generate good stratigraphic sequences (Trenches EI and $\mathrm{E}_{2}$ ) (figure $4 \mathrm{c}$ ).

This explains that the southern half of the höyük was the most promising for undertaking extensive excavation activities on levels related to the Ubaid culture. Subsequently, we discovered an interesting and promising small cone from the Early Bronze I in the central-western sector of Surtepe that stood directly on buildings of the Late Calcolithic period (Area $\mathrm{E}_{20-25}$ ), but it was not possible to continue with the extensive excavations before the end of 2010 .

The appearance of good stratified material of the earlier Late Chalcolithic phases (so-called local Late 

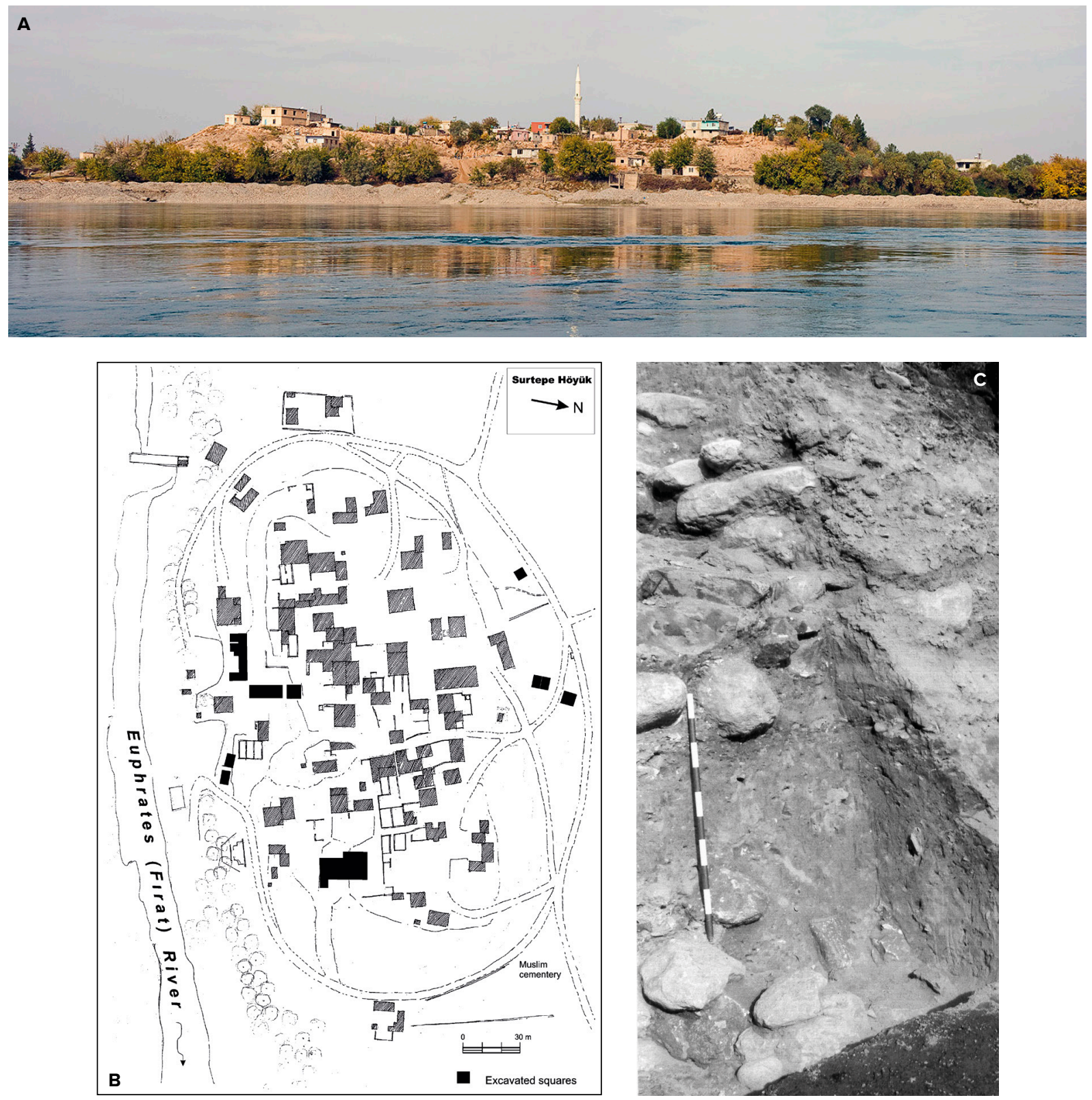

Figure 4. A. Surtepe Höyük (Birecik) on the Turkish Euphrates. B. Topographic plan of Surtepe Höyük and excavated squares. C. Stratigraphic sequence (Trenches E1 and E2). Surtepe Höyük

Figura 4. A. Surtepe Höyük (Birecik en el Éufrates turco). B. Plano topográfico de Surtepe Höyük y cortes excavados. C. Secuencia estratigráfica (cortes E1 y E2) en Surtepe Höyük

Chalcolithic 1-2) at Surtepe caused us to focus on these as well. The campaigns of last field work, prior to 2oro, were successful to determine the local relationship post Ubaid-Uruk cultural expansion (LC3-5 here) in the Birecik-Carchemish Area.

After the work at squares, $\mathrm{E}_{40-47}$, it seems that the Late Uruk materials substituted gradually there the Terminal Northern Ubaid or earlier stages of the local Late Chalcolithic 1 culture. We got there also later levels of the Late Chalcolithic 3 to 5 .
According to the evidence found in the soundings in the southern end sector of the höyük, Area C, the earlier Late Chalcolithic levels on Surtepe shows a few rebuilding phases of either mudbrick or stone foundation walls.

At Surtepe, the lowest levels reached in extension (perhaps late LC1 or earlier Late Chalcolithic 2 phases) shows a pottery sherdage almost identical to the material found nearby Tilbes Höyük, at Tilbes-Körche. We proved the extension of the Late 
Chalcolithic r levels in Surtepe for an area of at least 4 hectares in south and southwestern slopes. We have not sure yet if it was bigger then, but if it is verified that it reaches part of the northern part of the place, it will mean more than 6 hectares for the post-Ubaid settlement in the höyük. After the soundings there (at trenches $\mathrm{C}_{\mathrm{I}}$ and $\mathrm{C}_{2}$ ) plus the discovery of a few painted sherds during the last dig season in 2008, we are sure that at least Surtepe's occupation started in the Terminal Halaf phase.

In Surtepe, the older Ubaid materials (coming from the year 2000 soundings and surveys) display Coba bowls and there are slight changes in ceramic production with the addition of temper. Also, we note painted motifs on ceramic fragments with a different technology and ware typology than the before described for the Terminal Northern Ubaid/Late Chalcolithic 1 of the site. The material was then proper of a Northern Euphrates Late Ubaid phase. And it does not contain the hemispherical bowls of the post-Ubaid Körche site close to Tilbes Höyük (figure $\mathrm{I}_{3}$ and $\mathrm{I} 4 \mathrm{~b}$ ). A fragmented Ubaid ceramic boat, in yellowish buff, was found also at Surtepe in the $\mathrm{C}_{\text {I }}$ Sounding, very similar to the match found in Tell Zeidan in 2010, ZD8125 (Stein, 20II: I26, fig. 5).

After that Ubaid occupation, there is about one meter and half of river lime deposits and a more recent cultural occupation with Late Chalcolithic 1 culture or like materials. Scholars stressed years before the climatic changes in Southern Mesopotamia and in the Gulf region from moist to arid ca. $4000 \mathrm{BC}$ (Hole, 1994).

There is a long sequence of hiatus-free occupation between LC1 and maybe early 2 of Surtepe, consistent with the evidence in Trenches $\mathrm{C}_{1}-\mathrm{C}_{2}$ (figure $4 \mathrm{c}$ ), suggesting a strong culture and by no means a transitional phase between the local Late Ubaid and subsequent periods of the Late Ubaid excavated during some campaigns on the böyük. The Terminal Northern Ubaid pottery of Surtepe does not differ so much to the Körche Late Chalcolithic 1 settlement found close to Tilbes Höyük (figures $5 \mathrm{a}-5 \mathrm{~b}$ ).

Some motifs of painted ceramics in the Terminal Northern Ubaid tradition of Surtepe bear some similarities to those found in Tilbes-Körche (figures $5 \mathrm{a}-5$ b. 2-4 upright, $3-4$ downleft). But others
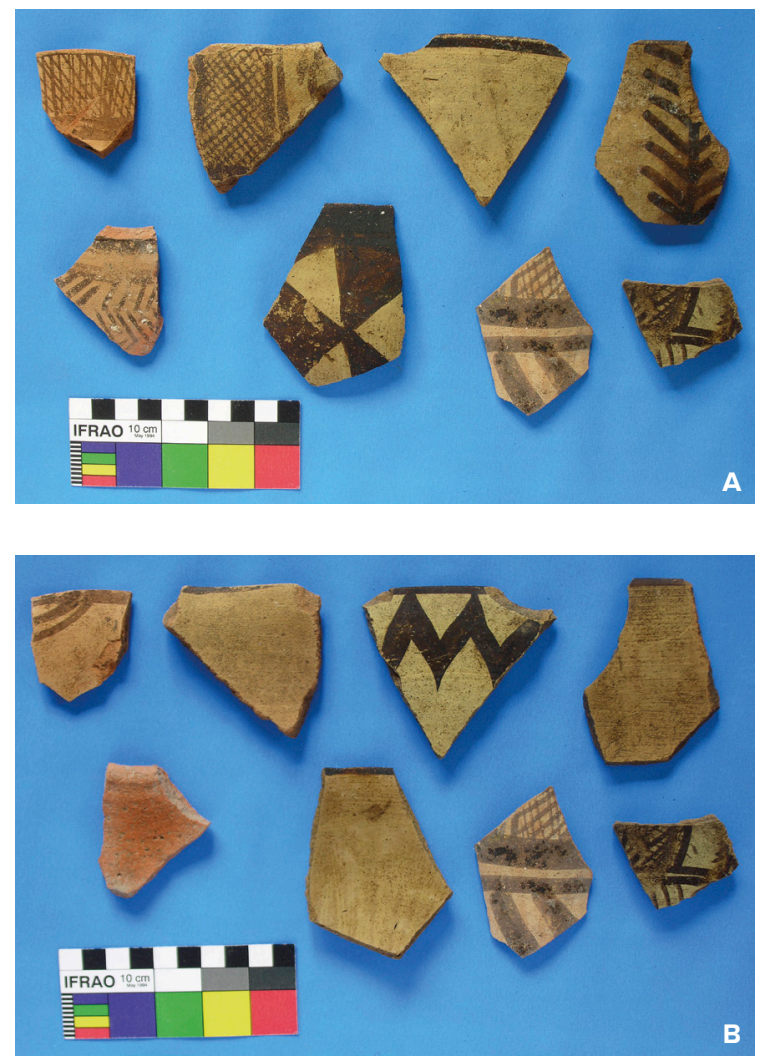

Figure 5. A. Late Chalcolithic 1-2 sherdage. Obverse. Area 40-45, Surtepe Höyük. B. Late Chalcolithic 1-2 sherdage. Reverse. Area 40-45, Surtepe Höyük

Figura 5. A. Fragmentos del Calcolítico Final 1-2. Anverso. Área 40-45, Surtepe Höyük. B. Fragmentos del Calcolítico Final 1-2. Reverso. Área 40-45, Surtepe Höyük

are absent in the Körche repertoire and show elements typical of the local Late/Terminal Northern Ubaid (figures $5 \mathrm{a}-5 \mathrm{~b}$. I upright, $\mathrm{I}-2$ downleft). In relation to Tilbes-Körche different pigments and different painters are appreciated in Surtepe.

On the other hand, some of the painted Surtepe fragments (figures 5 a- 5 b. 2-3 upright) do bear a resemblance to painted materials from the Tilbes Höyük found in the 1996 and 1999 surveys and associated with the first occupation of the tell in Tilbes.

The figure of Surtepe with a kind of geometric motif that resembles a branch of a plant (figures 5 a, upright), has a similar counterpart in a motif on the neck of a jug in Susa I (Steve and Gasche, I990: pl. I2.2). In Susa I ceramics appear deep bowls with painted exterior decoration; the ceramic percentage tends to the use of open forms with the appearance of bowls (Steve and Gasche, I990: pls. Io-II). There is also a tendency to use mineral degreasers in ceramic pastes. 
The trend in the phase Susa I is to use a series of repetitive painted motifs that do not occupy much of the surface in the bowls, in the jugs it is different, with a certain tendency to "horror vacui" (Steve and Gasche, I990: pl. I2-I4). Similar geometric motifs from Tilbes-Körche are reminiscent of several of those found at Tell Shelgiyya (Ball, 1997: fig. 4.319). Tell Shelgiyya has been labelled as a LC1 phase site (Oates, 20I2). We cannot ignore some kind of relationship between areas of southwestern Iran and Birecik at the end of the 5 th millennium, and not only based on stylistic parallels or formal preferences for ceramic recipients, but it is attested during the local LC3 phase in Hacinebi Höyük, when the bitumen was coming not only from southern Mesopotamia, but also southwestern Iran (Schwarz et al., 1999: 5; Schwarz and Hollander, 2008).

In Surtepe, the bowl and its type of geometric pattern and surface and quality of the ceramic seen (figure 5 a, top 2 right) it is very similar to that of the "Ubaid pottery" of Level VIII-XII of Telul eth-Thalathat II (Egami, I958: pl. L-I). But with respect to Tilbes-Körche, the bowls or jugs present in levels XIII-XIIb of Telul eth-Thalathat II (Fukai et al., 1970: pl. XLII-5, XLIII-3 and LXXI-I4) seem like a variant coarsest and most archaic of the ceramics present in Birecik.

During the Late Chalcolithic 1-2 phases, the stone tools show a high degree of local production and specialisation and were very abundant during the period. But on the site, obsidian is present but in small amounts and finished tools, suggestion a production out of Surtepe (Crivelli and Gil Fuensanta, 2008).

Metal fragments and also slag samples were chemical analysed by Hadi Özbal's team of Bogazici University (Istanbul). The results of the analysis of the samples covering a rooo-year period (since LC until late EB Age) were very close to each other (Özbal and Turan, 2002). The samples belonging to the Late Chalcolithic levels with a LC 4 date of Surtepe Höyük, shows a high degree of quality and technology for the copper from this area. The chemical analysis results of the samples analyzed as slag in Surtepe were similar to those of Tilbes Höyük, and the amount of copper and lead was very low (Özbal and Turan, 2002: 63, table 4). While arsenic was not observed in copper-based materials, high rates of tin were found in two samples. Of these, sample S-4033, I2 $\mathrm{gm}$, dated in the LC $4 / 5$ phase, it is a bronze piece with a $6.12 \%$ tin and has non-corroded metal parts.

\section{Late Chalcolithic 1-2 buildings at Tilbes Körche}

We note a high concentration of Halaf and Ubaid sites in this portion of the Euphrates (Birecik-Carchemish area). In the region, the same settlements seem to keep the occupation during the Halaf and Late Ubaid. They change at the very end of the Ubaid, during the so-called Terminal Northern Ubaid. And the settlement hierarchy which seems to start during the Late Ubaid times, could be seen again during the Late Chalcolithic 3-4 phases.

However, we stressed above the very little Late Ubaid and post-Ubaid culture data recovered for the archaeological stratigraphy of the Northern Euphrates and Tigris regions. The Birecik and Carchemish Salvage Dam Project sites in Southeastern Turkey were not a big exception.

Tilbes Höyük was the focal site for the Salvage Project on five adjacent sites on the Urfa bank of the Euphrates River, north of Birecik. There an (almost) uninterrupted sequence from Late Ubaid to Middle Bronze II was excavated thru years 1996 to 1999, with I6 meters of stratigraphic depth. The archaeological sites of Tilbes Höyük, Apamea acropole/modern Tilmusa, and Tilöbur, were flooded under the reservoir of the Birecik Baraji during the late spring and early summer of 2000 (figures 6a-6b).

In the Birecik area, most of the Late Chalcolithic 1-2 (on place) evidence comes from a one-period settlement nearby the already drowned Tilbes Höyük. This archaeological site was known to the local inhabitants as Tilbes-Körche (figure 6a). On the other hand, this site gives a further clue for its date because the original settlement on higher position on the hills east of Tilbes Höyük. After the investigations performed on the Late Ubaid occupation on the mound of Tilbes (the höyük), there was a hiatus (as consequence of a river flood) and 


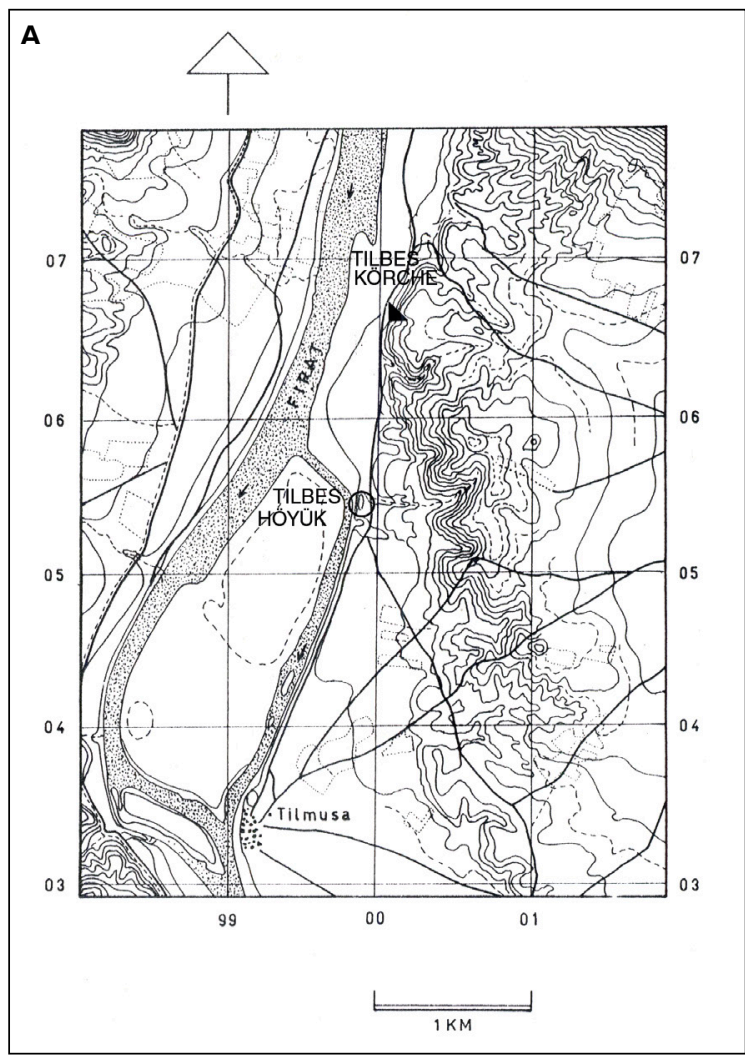

Figure 6. A. Map of the Late Ubaid Tilbes Höyük (circle), LC 1 Tilbes-Körche site (triangle) and Tilmusa/Apamea of the Tilbes Project in the Birecik Dam area. B. View of Tilmusa/ Apamea, Tilbes Höyük and Tilbes-Körche site on the Turkish Middle Euphrates

Figura 6. A. Mapa de Tilbes Höyük del Ubaid Final (círculo) y Tilbes-Körche del Calcolítico Final 1 (triángulo) y Tilmusa/ Apamaea dentro del Proyecto Tilbes en el área del pantano de Birecik. B. Vista de Tilmusa/Apamea, Tilbes Höyük y Tilbes-Körche en el Éufrates Medio turco

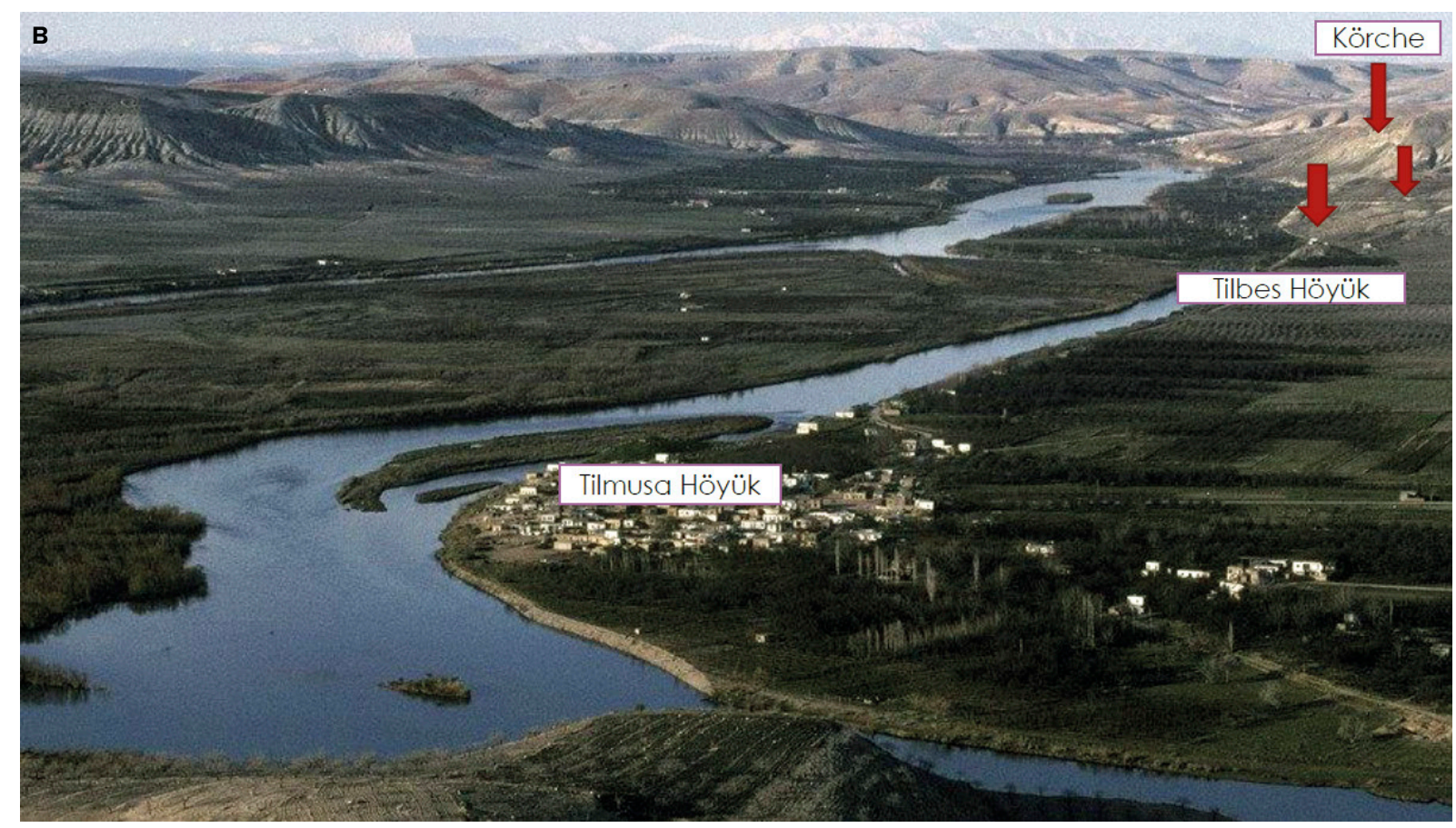

people must have just moved during the Terminal Northern Ubaid. We noted that flood also on the most important site for the Project, Surtepe.

There and between the years $200 \mathrm{I}$ and 2004, after our archaeological rescue activities in the post-Ubaid site of Tilbes Körche, close to Tilbes Höyük, we exposed over 450 square meters on this likely Terminal Northern Ubaid-related Chalcolithic settlement with at least a dozen of buildings salvaged. The site was occupied just one short span of time sometime after the end of Southern Mesopotamia Ubaid 4 phase. Because this only level of archaeological deposits 

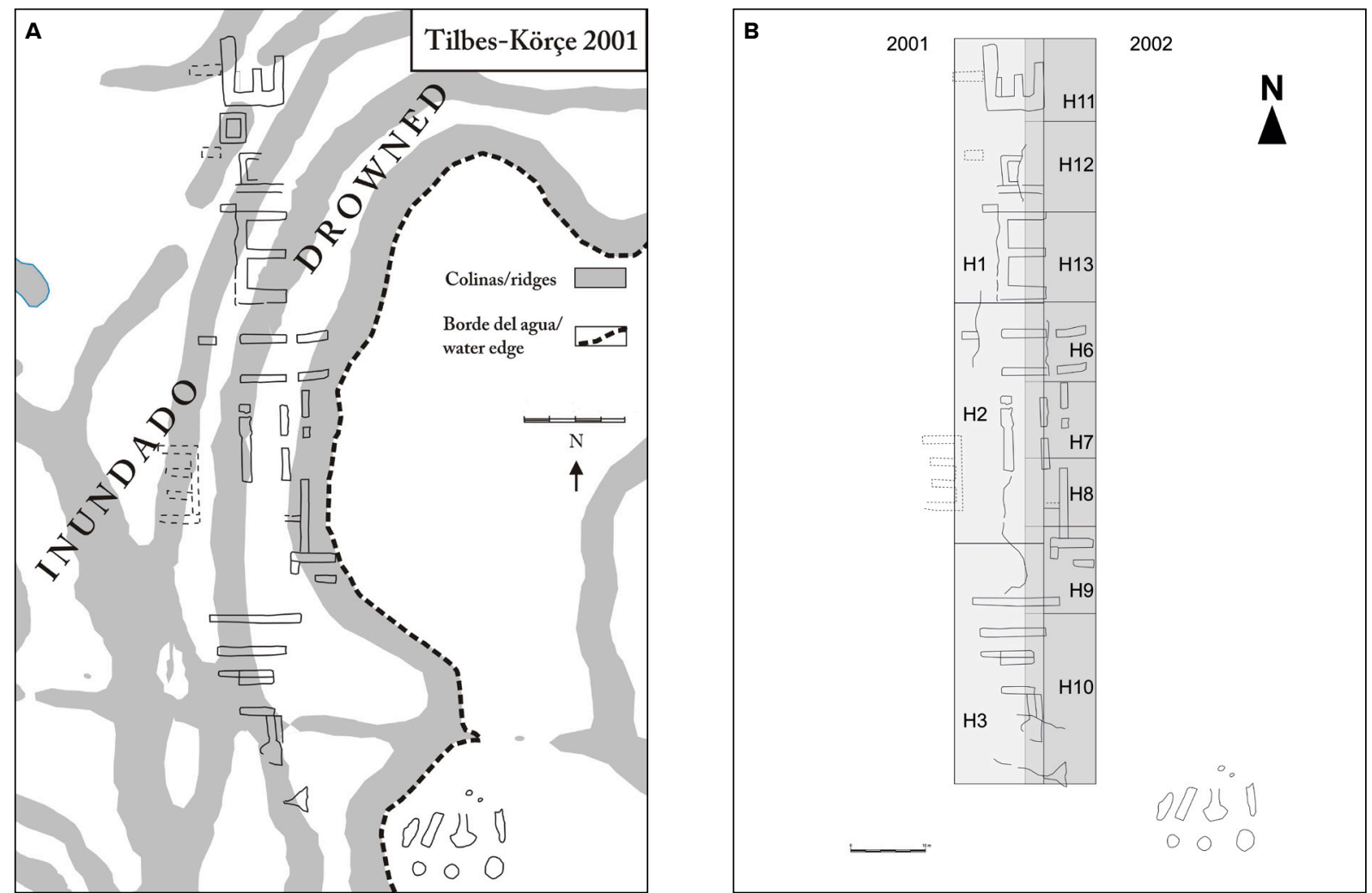

Figure 7. A. Topographic plan of the post-Ubaid settlement of Tilbes-Körche normally drowned in the Birecik Dam. B. Plan of the different excavation areas of Tilbes-Körche (2001-2004)

Figura 7. A. Plano topográfico del asentamiento post-Ubaid de Tilbes-Körche, normalmente inundado en el pantano de Birecik. B. Plano de las diferentes áreas de excavación de Tilbes-Körche (2001-2004)

and despite the case of the Dam waters drowning, we were able to determine all the concentrations of Northern post-Ubaid-like painted pottery and other associated artifacts (figure 7).

A dispersion of the ceramic (and decorated types) by areas has been demonstrated, as well as activities on the exposed surface. Having such extension of square meters excavated in Tilbes-Körche allows us to make various conjectures about the origin and evolution of post-Ubaid architecture in the Birecik area.

Those building plans show a well-planed site. We think in several of the site constructions as just a bigger inter-connected structure and no simple isolated buildings. Among the stone foundations we identify at least one tripartite and two typical bipartite buildings; one of those bipartite plants seems to be the northernmost building of the site (figures $8 \mathrm{a}-8 \mathrm{~b}$ ). To the west (flooded when we started our activities) and east of these bipartite plants, in the areas called $\mathrm{H}_{6}$ and $\mathrm{H}_{13}$, $\mathrm{H}_{12}$ and $\mathrm{H}_{11}$, there is the highest concentration of buildings of the place.
Just southeast of these structures, there is one of the highest concentrations of materials in the settlement, $\mathrm{H}_{9}$ (figure 9). Paradoxically, the areas north of this, $\mathrm{H} 8$ and $\mathrm{H}_{7}$, are the areas with the lowest concentrations of findings of this post-Ubaid site.

In the southern sector of Tilbes-Körche there is the largest excavated unit; such biggest tripartite building had a surface over 90 square meters (figure 7). It is the structure made up of units $\mathrm{H}_{3}$ and Hio (figures roa-roc).

On the same time, the most remarkable findings and highest concentration of post-Ubaid painted pottery also came from the largest excavated unit. The nicest findings inside it include a possible fragment of a limestone macehead, a stamp seal/amulet depicting a crosshatching motif (figure ira), a token with 8 incised lines (figure $\mathrm{IIb}$ ) similar to a stamp seal from Hacinebi B1 (Pittman, 1999: 47 fig. $2 / \mathrm{I}$ ), and traces of mineral ores and bitumen. Furthermore, the finding of the Körche amulet-seal reminds us from afar of the concept and motifs 

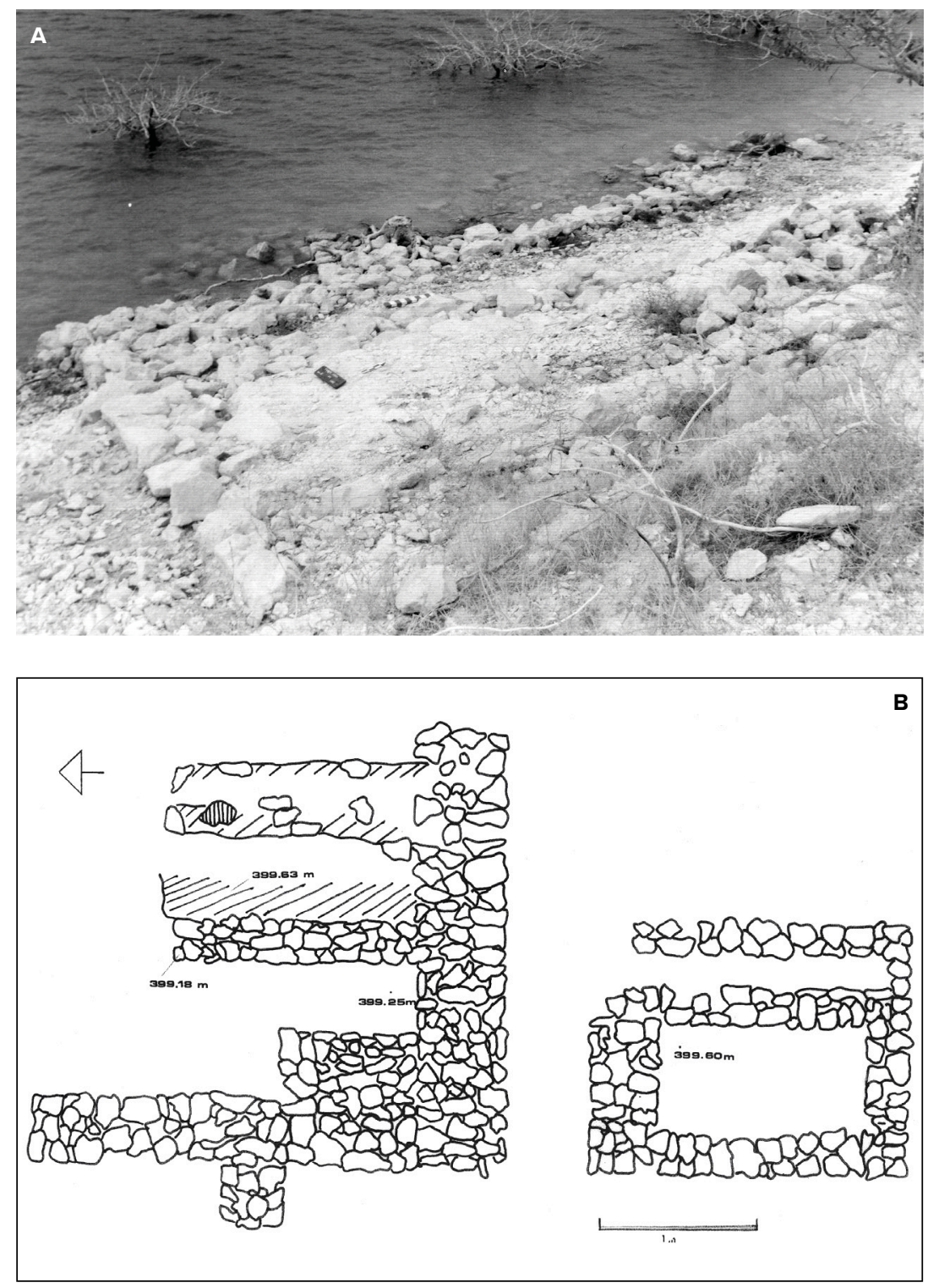

Figure 8. A. Area H1. Northern bipartite building. Tilbes-Körche. B. Area H1-H11. Plan of the northern bipartite building. Tilbes-Körche

Figura 8. A. Área H1. Estructura bipartita al norte, Tilbes-Körche. B. Área H1-H11. Plano de la estructura bipartita al norte. Tilbes-Körche

found (and with later date) at Tepe Gawra's diorite tablets (Speiser, I935: pl. XLIII, A-B). Paralells for the Körche finding could be seen at Tepe Gawra Ubaid levels (Tobler, I950: pl. CLVIII, 8).

On the other hand, there is a significant presence of the image of the cervid in some of the administrative elements found in Tilbes, both in the Höyük (figures IIc-IId) and in Körche. Identifies the presence of a gabled stamp seal in Tell Zeidan of LC2, made in "a red stone not native to the Raqqa region" (Stein, 2009: 314, fig. I4a) with a representation of a cervid, and similar to that gabled stamp seal found in the LC levels in the Tilbes Höyük A1 sounding, TB96.or4 (Gil Fuensanta and Misir, 1998: fig. 6.I) suggests some kind of connection or chain of exchanges between both regions at the dawn of the $4^{\text {th }}$ millennium BC.

Tilbes-Korche in a way presents both archaic features typical of an Anatolian settlement and a certain urban precedent, for its layout and buildings forming a typical disposal, such as the "agglutinant". There we know of previous structures excavated from the Neolithic in places like Zeytin Bahceli or Mezraa-Höyük/Teleilat (figure $3 \mathrm{~b} \mathrm{n}^{\circ} 7$ ). 


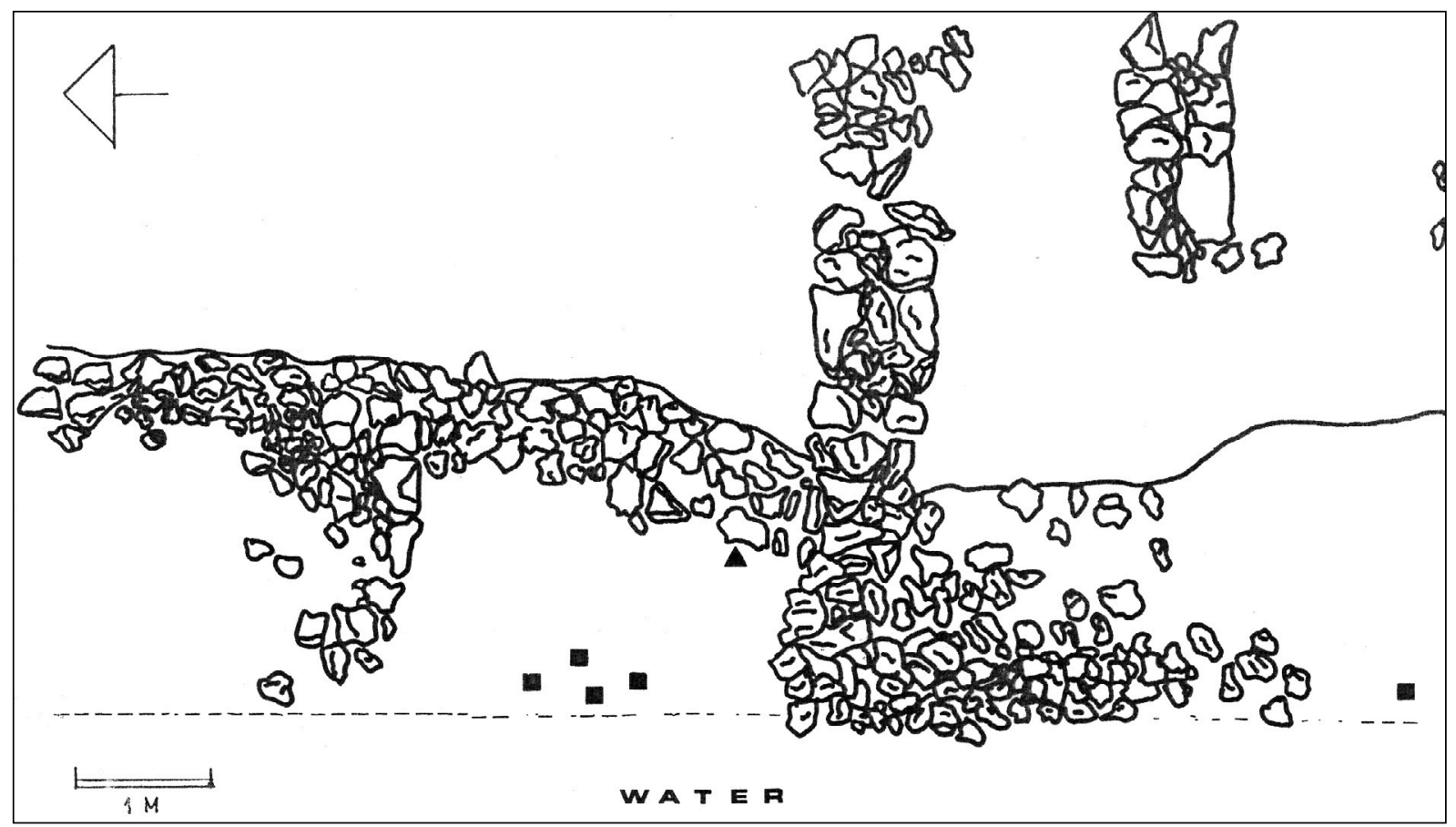

Figure 9. Area H8-H9. Plan of the southern bipartite building. Tilbes-Körche Figura 9. Área H8-H9. Plano de la estructura bipartita al sur. Tilbes-Körche

And we deduced from them that the presence of tripartite plants or buildings with multi-room connections was not new in the area.

We recall the parallel of Thelul eth-Thalatat in the northern Iraqi Tigris, near Mosul, dated Terminal Northern Ubaid, compatible with LC1 of our region, and which contributed a tripartite building, the so-called $\mathrm{C}_{17}$ construction (Egami, 1958 : fig. 25). The dimensions and nature of the contents evidenced there a domestic-residential use, but by status characters or with ritual attributions based on various findings in the central room (alabaster ceramic fragments, two maces, axes of various materials, niches on the short sides). It is the typical architectural culture of the North during Ubaid, since we did not find a clear division between domestic or ritual aspects, as was typical of the south during the period, a region where temples clearly existed since the $5^{\text {th }}$ millennium (Stein, 2010: $35 \mathrm{ff}$ ).

Bipartite architecture has been present on the Syrian Euphrates also since the Late Ubaid. At Tell al-'Abr, about $60 \mathrm{~km}$ south of Tilbes-Korche, there were bipartite structures, of similar dimensions, almost $20 \mathrm{~m}^{2}$, in their first two levels of occupation (Yamazaki, 2000: pl. 2-3). However, bipartite plants do not appear to be present in the Post-Ubaid phase of that site; on the contrary, the circular architecture of Tell al-'Abr does not appear among the excavated remains of Körche.

The interconnected ground plan of the buildings suggests their occupation by a group of closely connected people. We could think of an extended family occupying the place, but we have our doubts about its labyrinth character, or the lack of elements in favor of a strict domestic character. It was more a meeting place, based on the nature of open-shaped bowl ceramics and the large quantity of painted ceramics, with a certain repetitive meaning, which points to a redistributive place, and with some industrial characters (bitumen production) nearby. Bitumen still persists in the phase of occupation of Körche. In Tilbes-Körche $\mathrm{H} 1$ and $\mathrm{H} 2$ we find stone tools used in activities of handling the same material.

A parallel for some of the architectural features in Tilbes-Körche is found at the site of Kosak Shamali, across the Syrian-Turkish border, on the Syrian Euphrates, some $85 \mathrm{~km}$ downstream from Körche, and also situated on the shore left of the river. There it seems that the "Post-Ubaid" phase was also of little temporal extension. The bitumen 

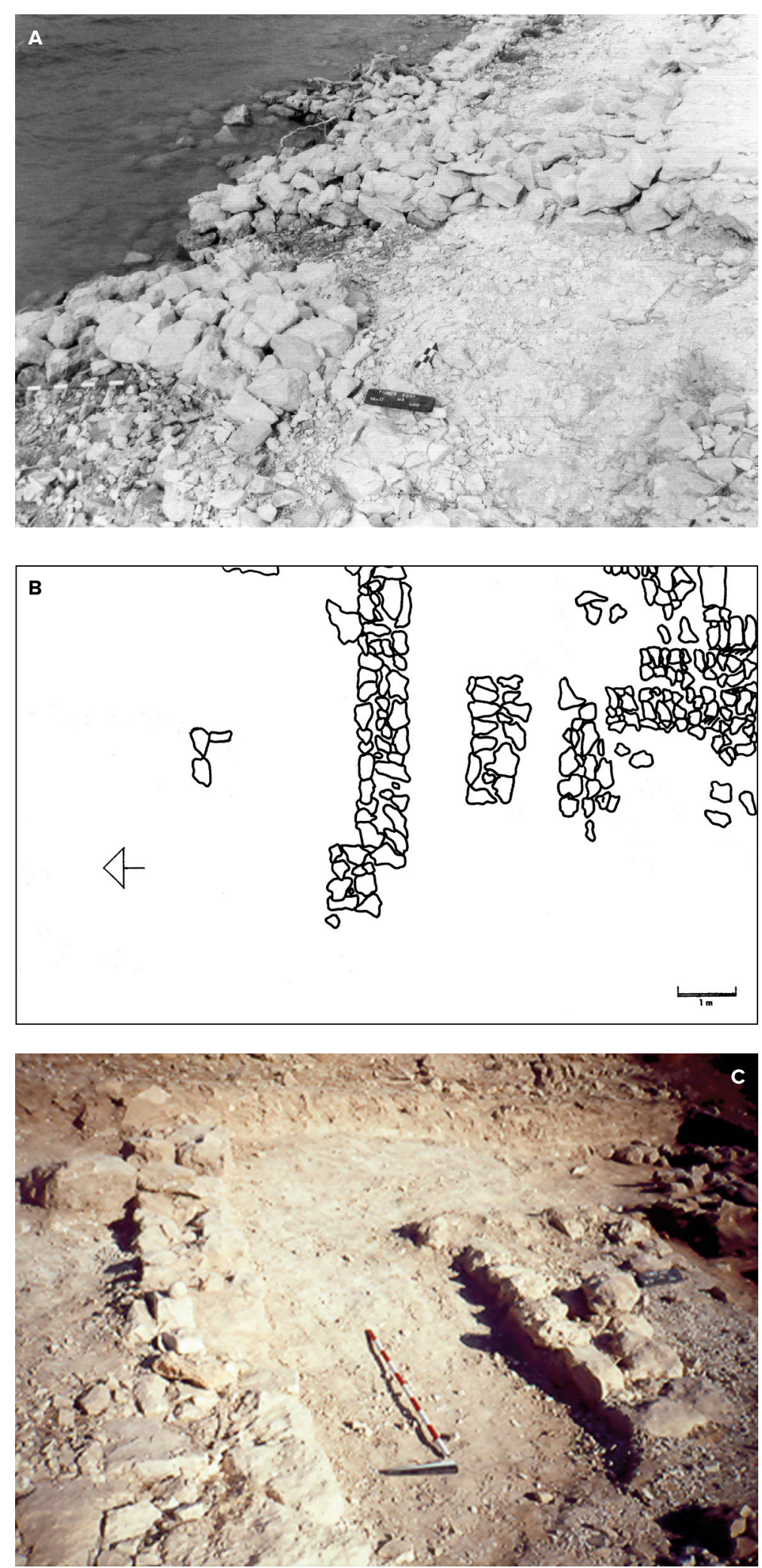

Figure 10. A. Area H3. The southernmost (multi-room) tripartite building. Tilbes-Körche. B. Area H3. Plan of the southern tripartite buildings. Tilbes-Körche. C. Area H3. Excavation of the southern tripartite buildings. Tilbes-Körche

Figura 10. A. Área H3. Estructura tripartita de varias habitaciones más al sur. Tilbes-Körche. B. Área H3. Plano de la estructura tripartita más al Sur. Tilbes-Körche. C. Area H3. Excavación de la estructura tripartita más al sur. Tilbes-Körche 

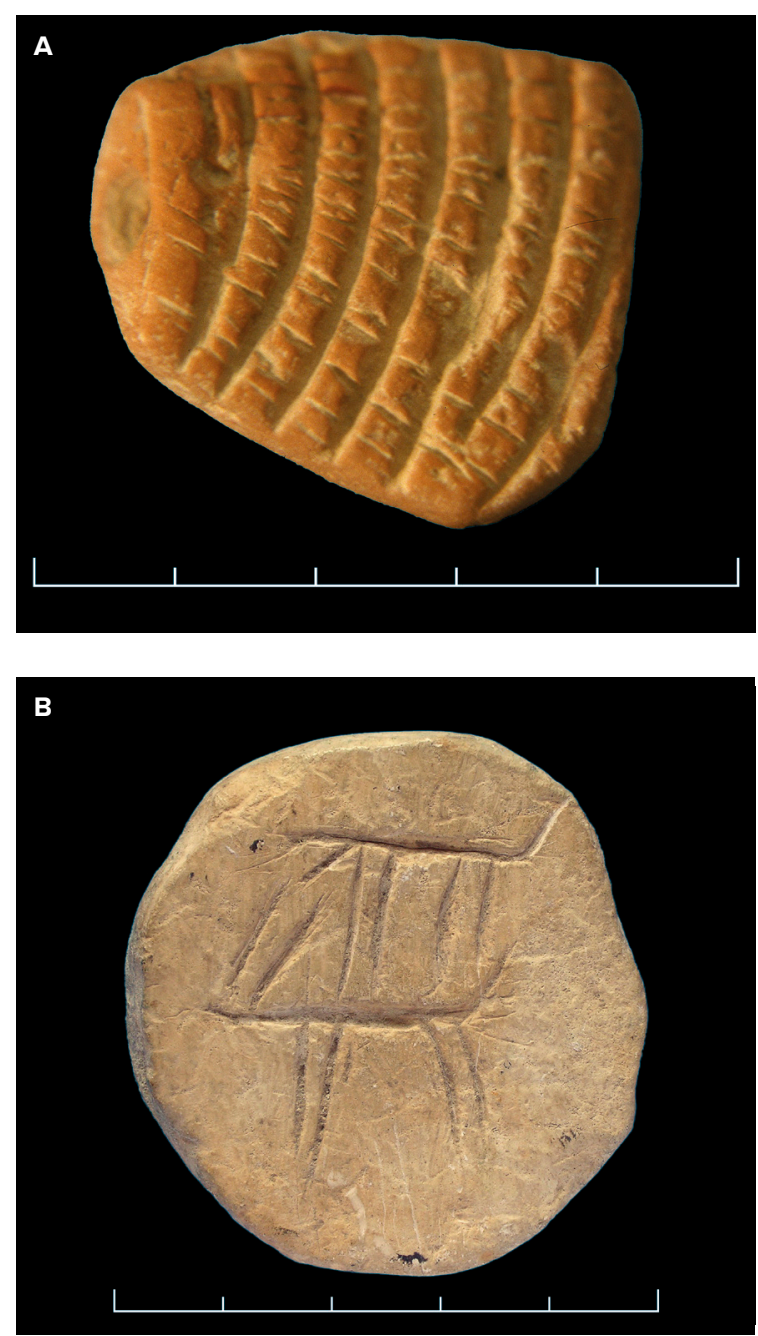

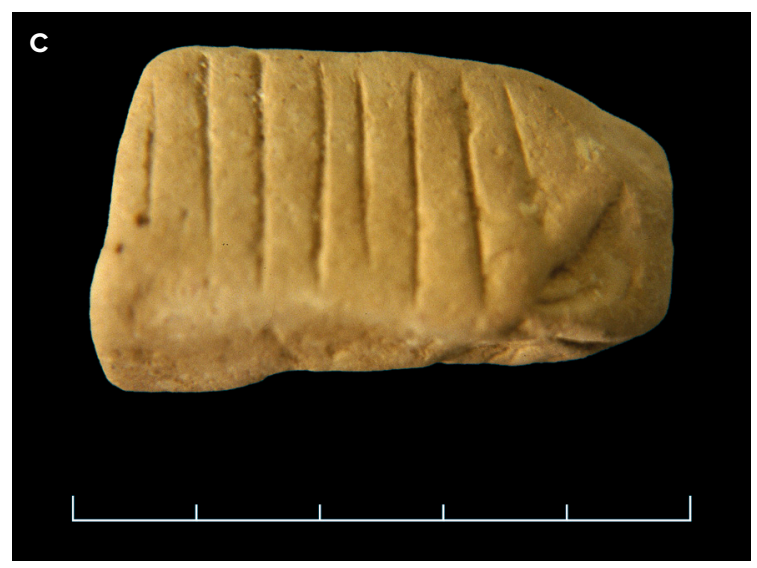

Tb. 96.014

D

Figure 11. A. Stamp seal/Amulet depicting a crosshatching motif. Tilbes-Körche. B. Stone token from the Tilbes-Körche site. C. LC Token with representation of a cervid, Tilbes-Körche. D. Gabled seal, read hematite, TB96.014 Tilbes Höyük A1 sounding, Tilbes Höyük (Gil Fuensanta and Misir, 1998: 242 fig. 6.1)

Figura 11. A. Sello/amuleto representando un motivo de líneas curvas. Tilbes-Kórche. B. Ficha/Token de piedra de Tilbes-Körche. C. Ficha/Token con una representación de un cérvido. Tilbes-Körche. D. Sello de hematites rojo. TB96.014. Sondeo A1 Tilbes Höyük (Gil Fuensanta y Misir, 1998: 242 fig. 6.1)

was of importance in the Late Ubaid levels of Tell Kosak Shamali and evidenced connections with areas of the northern Tigris. On the other hand, in the Late Ubaid era processed bitumen from central and northern Iraq was important (Nishiaki and Matsutani, 2003: 202-203). In a later context, LC3, the nearby Hacinebi offered evidence for the bitumen processing, which would be brought in blocks to the site. Hacinebi in Birecik demonstrates the presence of bitumen imported from Mesopotamia and western Iran (Schwartz et al., I999; Schwarz and Hollander, 2008).

To date, very scarce fragments of metal appeared at Tilbes-Körche site, but the presence of ores seems abundant. However, there are no elements that suppose that metallurgy was of importance in Tilbes-Körche, where it was vital for Degirmentepe's economic system. Körche has moderate animal remains, but little fish consumption; they were consumed as food in specific areas of the place. Furthermore, there are no recovered human remains.

The Tilbes-Korche walls suggest more abandonment than end in other ways, as there is no external action of fire on buildings or ceramic; valuable artifacts (stone mace, tokens, seal-amulet, or processed bitumen) appear to have been left in place and do not show any secondary fire. It seems the end of an abandoned place. 


\section{The Post-Ubaid pottery of Tilbes-Körche, Late Chalcolithic 1 and early LC2}

About $18 \%$ of the pottery found in the Tilbes-Körche buildings was painted. And among the typology, the bowls, plus various types' jugs with unique painted motifs associated, predominate. Painted ceramics of Tilbes-Körche have similar high percentages as other settlements of the second half of the $5^{\text {th }}$ millennium in various areas of Northern Mesopotamia and southwestern Iran. Very close settlements in the Middle Euphrates, such as Tell al-'Abr, even show very high percentages of painted ceramics during their $5^{\text {th }}$ millennium sequence, always exceeding more than half of the ceramic ensemble in many of the phases (Hammade and Yamazaki, 2006; Yamazaki, 2000). At Tell Leilan VI, in the Khabur, painted ceramics make up about $40 \%$ of the set (Schwartz, I988). At the Khabur, Tell Hamoukar Level 4 presents a percentage very similar to our painted ceramics (Jayyab, 20I2).

The unpainted bowls are about half the ceramic ensemble, reminiscent of other settlements at the dawn of the Late Chalcolithic, such as Tell Hammam et-Turkmann (Akkermans, I988: II9) or Coba Höyük (du Plat Taylor et al., I950).

It is interesting to stress the huge abundance of bowls, but an absence of Coba bowl sherds. And we believe it as a track for a proper chronological setting of the $\operatorname{site}^{1}$. A lot of pot fragments from the site present traces of a wheel or slow-wheel. The gritty percentage of the ware would place it on the Late Chalcolithic 1 or very early into the LC2 (Rothman, 200I). In conclusion, we place it on the Post-Late Ubaid period.

An element that we are clear about is that the time sequence of Tilbes-Körche is prior to the Arslantepe VII (Malatya, Upper Turkish Euphrates) or Hacinebi A (Birecik) phases, which are two of the clearest archaeological sequences of the Late Chalcolithic 2-3, Early Uruk in Southern Mesopotamia.

1 But for any instance, we could no use painted motifs as a chronological guide.
It is possible that most of the ceramics found in the LC1 of Körche were produced in the Birecik area itself. However, Tilbes-Körche painted ceramics demonstrate at least a presence of some non-locally produced ceramics.

Concerning the pot typology of the site, they are common open shapes bowls with sharply incurved, hemispherical bowls (figures I2a-I2b) but no real "Coba" bowls. There is also a presence of either outturned-rim bowls, or inturned bowls. This very distinctive type of Körche ceramic bulk is an open bowl that looks like a derivation of the classic flint-scraped, and never is painted; it is very common in Hio (TBo2Hio-28). It seems very different from the "classic" flint scraped bowls found at Tilbes Höyük in 1999.

The bowls with inner flint scraped in Tilbes-Körche present it in their half or upper part (figure I2), and they have mineral temper and buff color, as well as in the LC1 specimens from Tell Zeidan (Fisher, 20I7: pl. 23, r); both also feature a bead rim. Bowls of this type produced in series at Körche reveal the use of their elaboration either by means of molds or with a wheel. In a way, the inner flint scraped bowls of Tilbes-Körche are a variant of the so-called wide flower pots, chaff tempered, which appear from LC1 to LC3 of Northern Mesopotamia. In Körche there are other bowls that are also a variant of the wide flower pots (figure ${ }_{5} \mathrm{c}$ ).

Bowls of the flint scraped type, Coba or in some of its variants, handmade and with flat bottoms, appear in Hamam VA (Akkermans, 1988: 120), Tepe Gawra and Mersin XIII-XIV. They appear in Tell Zeidan from the local Late Ubaid and survive during LC phase 1 (Fisher, 20I7: pl. 23-24). The interior-incised deep bowls looks like a feature of $\mathrm{LC} 1$ and the beginning of LC2 (Baldi, 2OI2: I43).

Other wares include cup-like vessels, globular jars with round bases and small pots. The most usual jar types are with short everted necks, with overhanging rims or with high necks.

The surface of Körche ceramics generally has a rougher surface than is usual for other Late Ubaid ceramics. In the non-decorated bowls elaborated in mass, straw or coarse sand inclusions are noted, which refer us to the techno-ceramic ensemble of Tepe Gawra XI A (Tobler, I950: 152). 

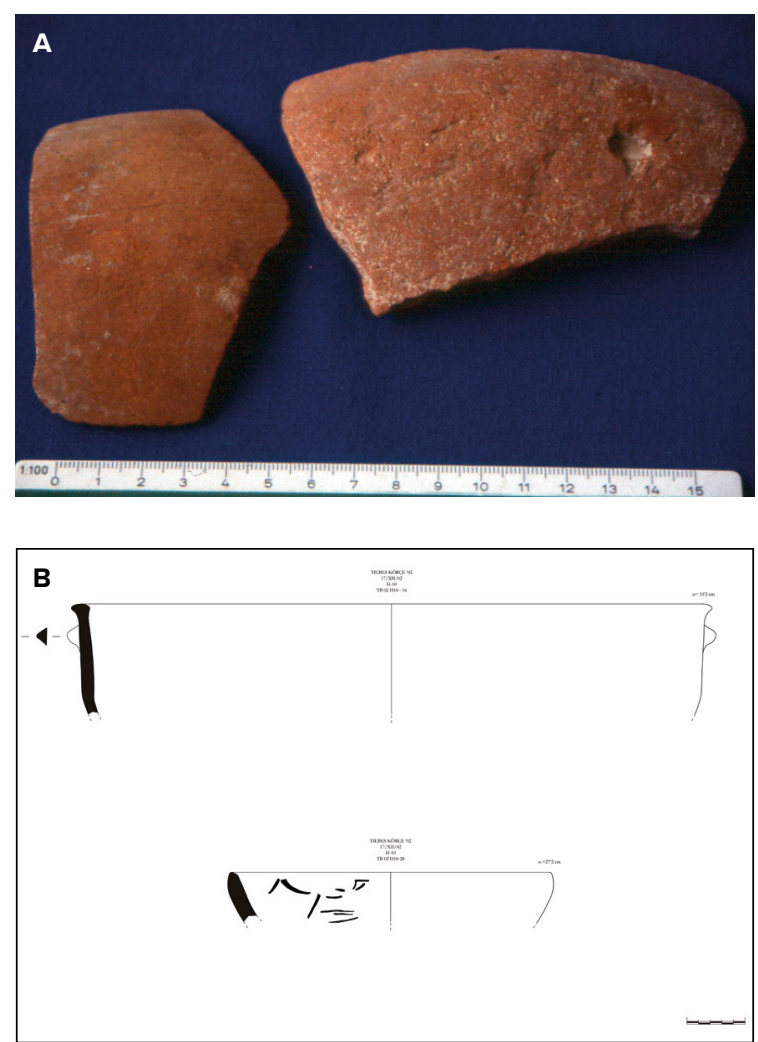

Figure 12. A. Hemispherical bowls with inner flint scraped. Tilbes-Körche. B. Inturned open bowl with inner flint scraped (TBO2H10-28). Area H10, Tilbes-Körche

Figura 12. A. Cuencos hemiesféricos con decoración grabada al interior. Tilbes-Körche. B. Cuenco de paredes convergentes con decoración grabada al interior (TBO2H10-28). Area 10. Tilbes-Körche

It could be also somewhat striking that in the Southwest of Iran during the dawn of the fourth millennium, in the local period called "Protoliterate" of Choga Mish, dated to the local Late Susiana (whose Late Susiana 2 phase, that of Susa I/A is equivalent to part of the LC1 of Northern Mesopotamia), a large number and variety of bowls are presented, some of which by their invoice could resemble those of Tilbes-Körche (Delougaz, Kantor, Alizadeh, 1996: pl. 84). However, the only flint scraped vessel of the period in Susiana seem to be more conical, flat base, and flower pot-like bowls, absent in Tilbes-Körche, and unparalleled in the Upper Tigris.

The bead rim vessels have a certain percentage within the sample of Körche's non-decorated bowls. They were common in Tell Hammam et-Turkman during both periods $\mathrm{IV}$ and $\mathrm{V}$, and appear in Sakce Gozu IVB-IVC. The carination is typical of Hammam V B vessels (Akkermans, I988: fig. 9:I50).
The pottery was painted in dark-brown, black and just occasionally some red. For the site, we detect just a few and repetitive motifs on the painted pottery, and mostly a combination of several of them. A huge amount of the unusual motifs of painted pottery come from the "biggest building" (figures $\mathrm{I}_{3} \mathrm{a}-\mathrm{r} 3 \mathrm{~b}$ ); the exceptions to this rule are a few ceramic fragments found in northern bipartite and tripartite buildings. In general terms, inside the "biggest building”, appeared most of the sherdage showing painted subjects of schematic or a geometric type of anthropomorphic figurines (figure $\mathrm{I}_{3} \mathrm{C}^{2}$. We could see them in different combinations with geometric designs (such as horizontal or vertical lines, cross-hatch or waves). On the other hand, those mentioned simple designs are the usual motifs for the painted pottery of the site ${ }^{3}$. Anyway, the scarcity of motifs and patterns suggests a bigger standard than usual in Southern Mesopotamia Late Ubaid Phases 3-4 into the pottery production of the Late Chalcolithic 1 site of Körche.

Among the sample of the motifs appeared in the other buildings, we could distinguish also the mentioned simple patterns. But among the unusual ones just remark a human face-like (figure I3a, down, center) and the decoration of a spouted-jar (figure $\mathrm{I}_{3} \mathrm{~d}$ ).

The open painted bowl is very common in the Tilbes-Körche techno-ceramic ensemble; it appears in several buildings (HI, Hro) and seems that the painted bowls are concentrated in $\mathrm{H}_{\mathrm{I}}-\mathrm{H}_{3}$. The most common of the painted bowls is a very common type in one of the bipartite units, $\mathrm{H}_{2}\left(\mathrm{TBoIH}_{2} / 84-\mathrm{I}\right)$ (figure I4a).

In Körche a red-painted pottery appears that is no different from the red-burnished ware that appeared in the Surtepe LC levels. It is about painting the same motifs that appear with the color black or dark brown in the rest of the painted

2 There is a presence of antropomorphic figurines on painted Halaf sherds of the Birecik area (with earlier date in the Neolithic crossing the Syrian border at Tell Halula, and the Halaf levels at Tell Amarna).

3 General geometric motifs have a huge spread since the earlier stages of Late Chalcolithic across Northern or South Mesopotamian regions as dots (in Degirmentepe), ladders, inclined rectangles and waves (present in Southern sites as Al-Ubaid or Gawra in the North). 

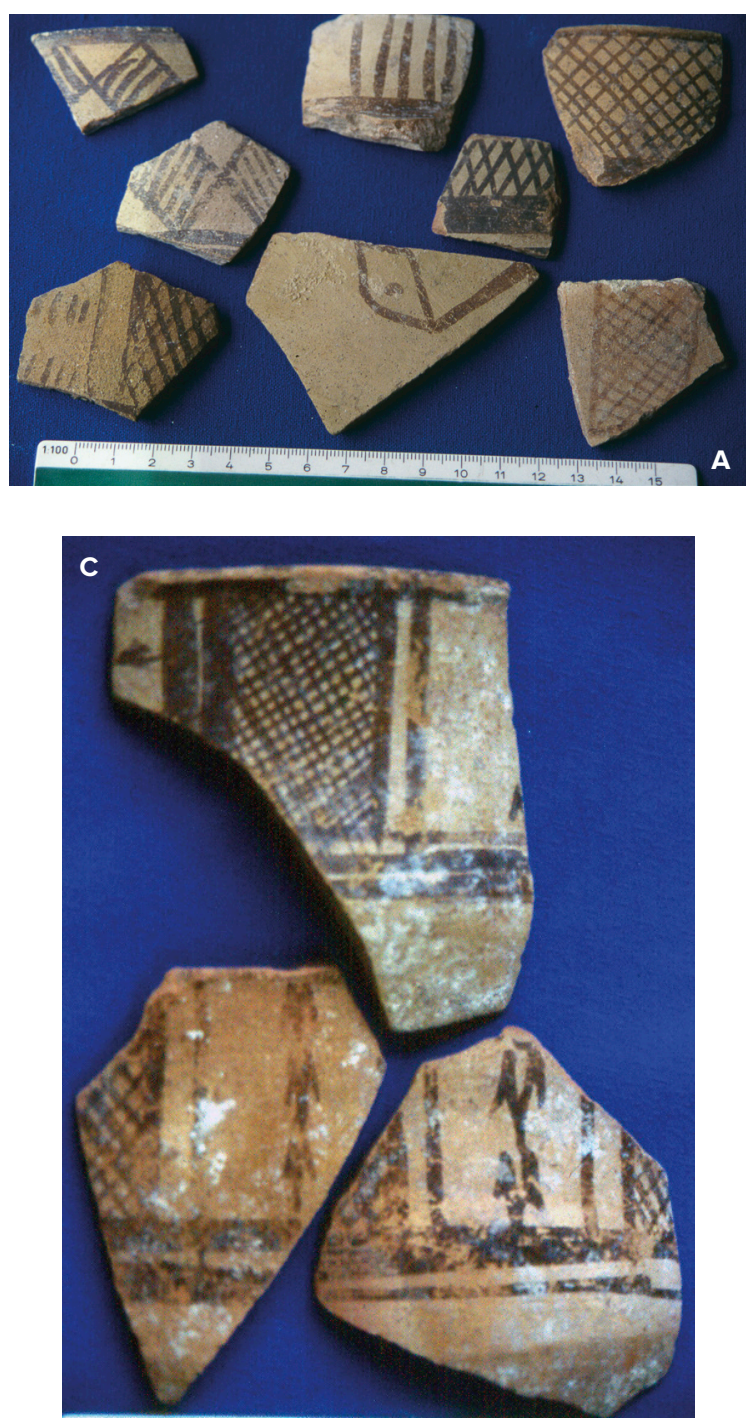

specimens; but we never see it with the most complex painted patterns such as the cross-hatched or the human figures. They are almost always straight lines or waves, the reddish painted motifs.

Painted simple rim globular bowls, such as those in the Balikh (Fisher, 20I7) or in the Khabur (Baldi, 20I2) have not been discovered in Tilbes-Körche. However, these shapes with representation of the cross-hateched and next to them two black triangles facing each other (by the way, an undiscovered pattern between the specimens of Tilbes Körche or Surtepe), they are present during LC1 of Tell Zeydan (Fisher, 20I7: pl. 25 1). But in both places the temper is mineral and in greenish color wares. The Tilbes-Körche specimens with the cross-hatched patterns and human figures or other similar motifs are always found on carinated shapes, more typical of those of Tepe Gawra XI-IX.
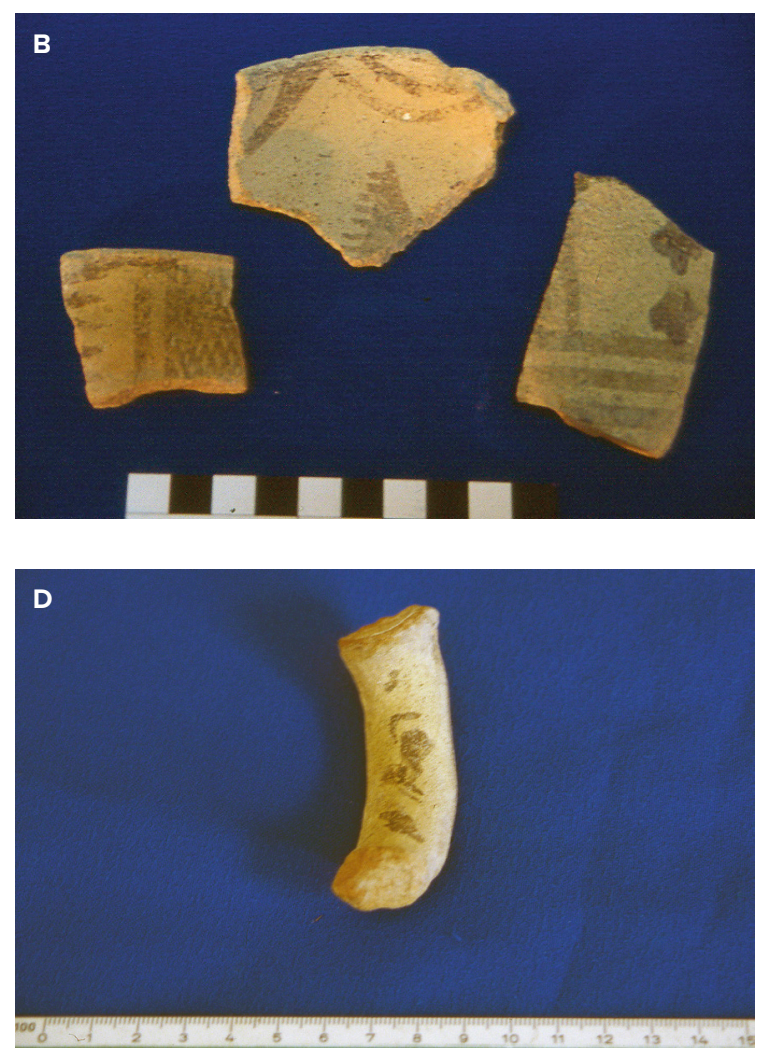

Figure 13. A. Repetitive motifs on the painted pottery. Tilbes-Körche. B. Sample of fragmented painted bowls. Tilbes-Körche. C. Painted Geometric anthropomorphic figurines on a sample of fragmented bowls. Tilbes-Körche. D. Painted signs on the reverse of a jar lug. Tilbes-Körche

Figura 13. A. Motivos repetitivos en la cerámica pintada. Tilbes-Körche. B. Fragmentos de cuencos pintados. Tilbes-Körche. C. Figuras antropomorfas en una muestra de fragmentos cerámicos. Tilbes-Körche. D. Motivos pintados en el reverso del asa de una jarra. Tilbes-Körche

Another type of bowl, more elongated, and therefore more in line with a post-Ubaid derivation of the Coba bowls is that type $\left(\mathrm{TBo}_{2} \mathrm{H}_{7}-\mathrm{I}\right)$ that we find concentrated in area $\mathrm{H}_{7}$ (figure $\mathrm{I}_{4} \mathrm{~b}$ ). Some of these bowls are painted with one of the most recurring motifs among Körche's iconography: the "cross-hatch" ( $\left.\mathrm{TBo}_{2} \mathrm{H}_{9}-2\right)$; such specimens are concentrated in area $\mathrm{H}_{9}$ (figure $\mathrm{I}_{4} \mathrm{e}$ ). One type of bowl has a pedestal ( $\mathrm{TB}_{2} \mathrm{H}_{9-7}$ ); and in Körche it concentrates on $\mathrm{H}_{9}$. Pottery sherds of bowls or other open forms, with painted anthropomorphic figures abound in $\mathrm{H}_{3}$ (figures I2c, c, I4d). A bowl without painted figures, from the Hro (ТВогНiо-г6) has internal secondary cremation, but we do not know if it was used for cooking or ritual.

The painted pattern representing the "leaning triangles" is, however, identical to another one in relief 


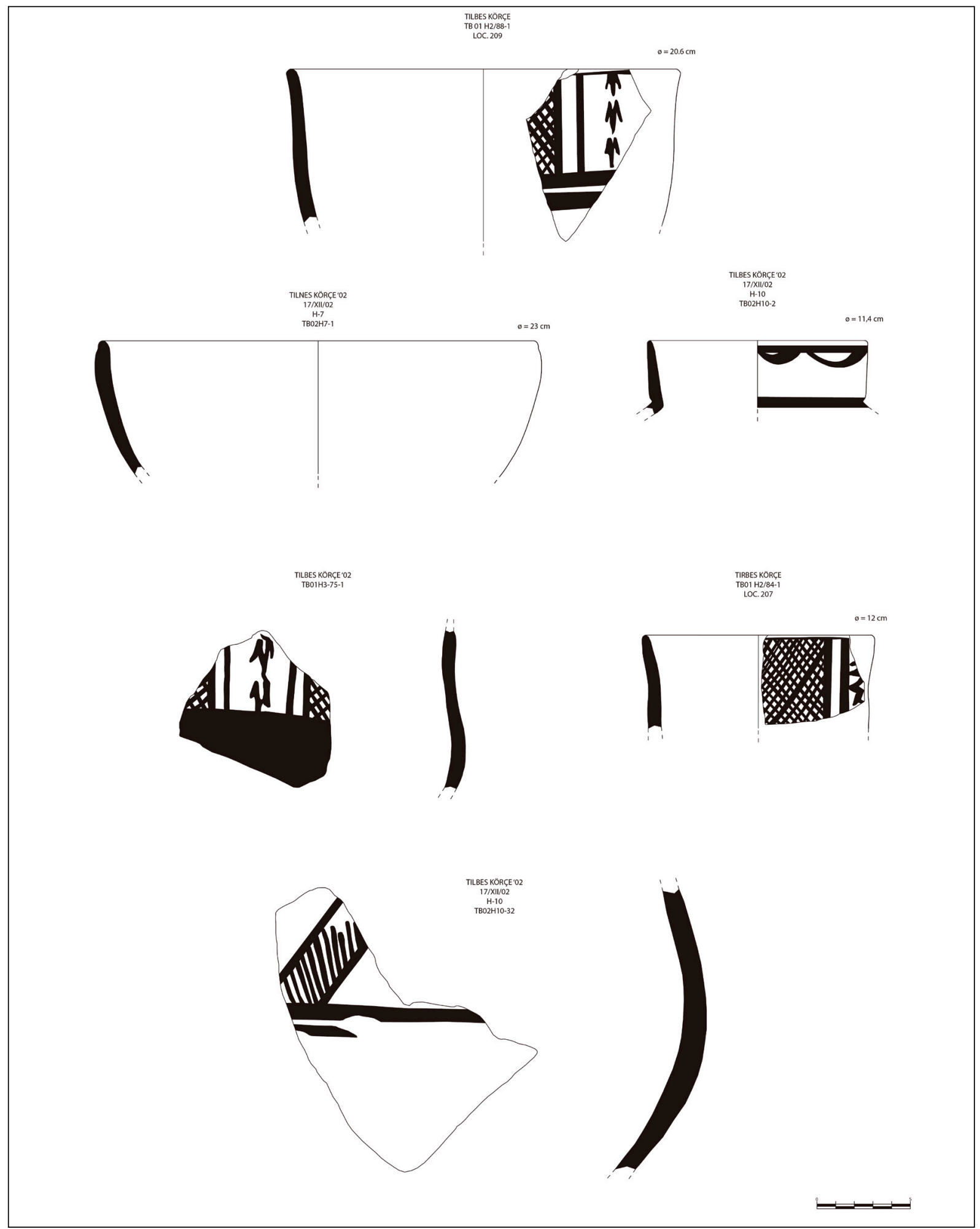

Figure 14. A. Common painted bowl of the bipartite plan (TB01H2/84-1). Area H2, Tilbes-Körche. B. Unpainted bowls (TBO2H7-1). Area H7, Tilbes-Körche. C. Frilled neck pot with geometric painting of waves and bands on its neck (TBO2H10-5). Area H1O, Tilbes-Körche. D. Open bowl, with painted figures (TBO2H395-1). Area H3, Tilbes-Körche. E. Latticework of lines on painted bowl (TBO2H9-2). Area H9, Tilbes-Körche. F. Painted rectangles joined with internal stripes on open hand-made bowl (TB02H10-32). Area H10, Tilbes-Körche

Figura 14. A. Cuenco pintado de la estructura bipartita, H2 (TB01H2/84-1). Área H2. Tilbes-Körche. B. Cuenco liso (TBO2H7-1). Área H7, Tilbes-Körche. C. Cuello con pinturas geométricas de bandas horizontales y semicírculos. D. Cuenco abierto, con figuras pintadas (TBO2H395-1). Área H3, Tilbes-Körche. E. Líneas entrecruzadas en cuenco pintado (TBO2H9-2). Área H9, Tilbes-Körche. F. Rectángulos pintados unidos en un cuenco a mano (TB02H10-32). Área 10, Tilbes-Körche 
and unpainted in Tepe Gawra XI-IX (Tobler, 1950: pl. LXXX,a.8). A similar painted motif to the "leaning rectangles" that appears on similar ceramics to that of Tilbes-Körche, simple painted fine ware, seems to be present in the Syrian Orontes, as demonstrated by Hama $\mathrm{L}_{3}$ a, a phase attributed to LC1-2 (Giannessi, 20I2: 270, 289, fig. 15.3). However, a painted motif interpreted as typical of the Late Ubaid (Fisher, 20I7: 385), the hatched triangle inside, appears absent among the patterns represented in Tilbes-Körche.

The necked globular jar seems to be one of the constants in both Late Ubaid and LC1 of the sites investigated in our Birecik project; it seems derived from some prototype of the Halaf culture. In Körche, however, this ceramic type appears beaded-rim and with geometric painting of waves and bands on its neck (figure I4c). Although it is not a characteristic type of Körche (but it is in $\mathrm{H}_{3}$-Hio), his painting is one of the most common among the percentage of painted motifs. Other pots painted with similar wave and band motifs on their necks also appear in $\mathrm{H}_{2}, \mathrm{H} 6$, and $\mathrm{H}_{1 \mathrm{I}}$ (TBo2H6-I and TBo2 $\mathrm{HII}_{\mathrm{II}}$, $\left.\mathrm{TBoIH}_{2} / 79-\mathrm{I}\right)$. With which it seems that it has a very precise dispersion according to certain places of the post-Ubaid settlement of Körche.

One of the most recurring painted motifs among the repertoire is the repetition of several rectangles joined with internal stripes (figures I4f, I5a). It does not appear limited to any ceramic form or exclusive area, but it is true that there is a concentration of it in various points of the archaeological site. Area $\mathrm{H}_{3} 3$ shows a predominance of this motif over open bowls, refined and made with mold or with some care (TBo2 $\left.\mathrm{Hr}_{3}-3\right)$ (figure ${ }_{5} 5$ ); but in sector Hro it appears painted on a type of bowl-pot, paunchy, coarser, hand-made (TBo2Hio-32) (figure ${ }_{4} f$ f). By other analogies we think that such a painted motif can mean "united buildings or people/families", in short, an alleged symbol of union.

Another of the most common painted motifs on Körche ceramics is the latticework (figure ${ }_{5} \mathrm{~b}$ ). We see it in deep bowls (TBo2Hi2-2) or in a pot ( $\left.\mathrm{TBo}_{2} \mathrm{H}_{3}-2\right)$. The shape of the open bowl appears associated with the lattice decoration, along with figures (but headless) at locus 209 of $\mathrm{H}_{2}\left(\mathrm{TBoIH}_{2} / 88-\mathrm{I}\right)$.
Jugs with painted long wavy bands on the neck are common in area $\mathrm{H}_{12}$ (TBo2 $\mathrm{H}_{12}-5$ and $\mathrm{TBO}_{2} \mathrm{H}_{12}-\mathrm{I}$ ). Another type of jar, very open, has paint on the edge and near the neck, with a motif of vertical lines between two bands, and where the lower one is thicker (TBo2Hi2-6) (figure I5g).

A small bowl, like a drinking pot, with the border stroked, and unpainted, appears in two variants (TBo2Hio-28 and TBo2Hio-i9) (figures ${ }_{15} \mathrm{C}-\mathrm{I}_{5} \mathrm{~d}$ ). Another of the typical forms resembles this one, and it is a small bowl with an outward edge, which shows parallelepipeds in its decoration (TBo2Hio-8) (figure 15 e).

One of the most unusual decorated forms appears in this sector. It is a jug with a lug, with curious geometric decoration of lines with different thickness, and that have a certain air of "horror vacui" (TBo2Hio-3) (figure $\mathrm{Iff}_{5}$ ).

In principle, very unusual could seem the apparition of several painted motifs on the reverse of a jar lug (figure I2c). A parallel has been found at Surtepe. In certain way, they far could recall some pictographic-like signs. We just remind the possible pictograms, with earlier date (Late Ubaid), found on stamp-seal imprints on the Late Ubaid site of Degirmentepe (Malatya), now drowned by the Karakaya Dam (Esin, 1994: 67, fig. 7.6).

One of the most enigmatic motifs is that of the anthropomorphic stylized figures (figure I2c). This seems to have two variants, the most common with a stylized full figure (figure $\mathrm{I} 4 \mathrm{~d}$ ), and another where the heads seem to be missing (figure I4a). The figures do not appear isolated, but in groups of three. It is not very abundant, although we find a few dozen ceramic specimens, always open bowls, with this painted iconography. And above all, its dispersion area is concentrated in three points: $\mathrm{H}_{2}, \mathrm{H}_{3}$ and Hro. In certain way, the heads of the stylized figures represented on the ceramics are reminiscent of the serpentine heads of the Western Iran figures found on levels of the Susa I phase (that is, Terminal Ubaid).

A painted but very unusual iconography into the Tilbes-Körche repertoire is the theme of the "geometric eye" (TBo2H6-4) that we only see in a copy of $\mathrm{H} 6$ (figure I2a). The representation is a very schematic version of what is known as "protruding eyes" in contexts of LC1 of northern Mesopotamia as Tell Feres al Sharqi. 


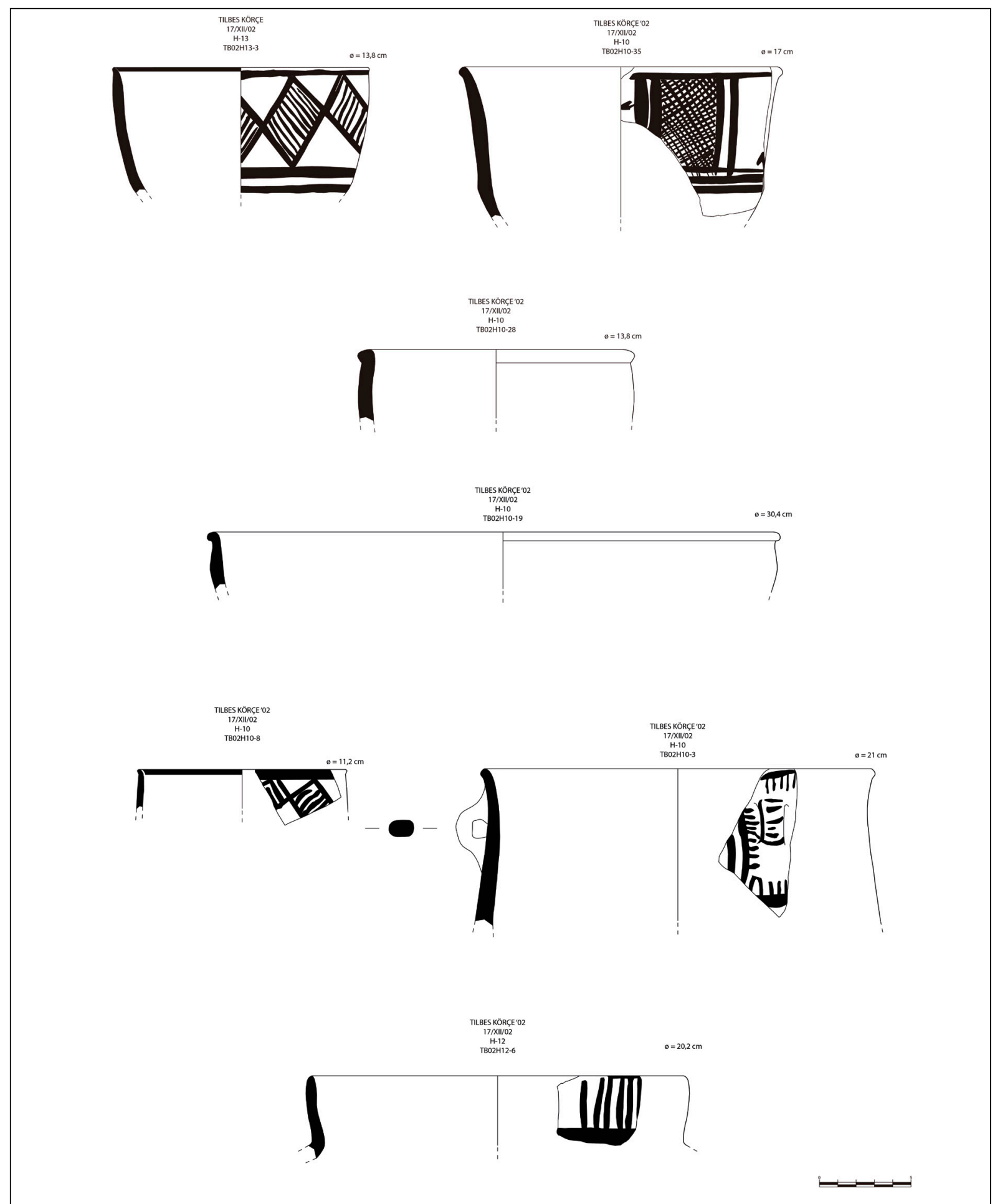

Figure 15. A. Painted rectangles joined with internal stripes on open mold-made bowl (TBO2H13-3). Area H13, Tilbes-Körche. B. Painted latticework on deep bowl (TB02H1O-35). Area H1O, Tilbes-Körche. C. Small unpainted bowl (TBO2H10-28). Area H1O, Tilbes-Körche. D. Unpainted bowl (TB02H10-19). Area H10, Tilbes-Körche. E. Small bowl with painted parallelepipeds (TB02H10-8). Area H1O, Tilbes-Körche. F. Jug with lug, and painted decoration (TBO2H1O-3). Area H1O, Tilbes-Körche. G. Open jar with painted vertical lines between two bands (TB02H12-6). Area H12, Tilbes-Körche

Figura 15. A. Cuenco hecho a molde con rectángulos pintados unidos por líneas horizontales (TBO2H13-3). Área H13, Tilbes-Körche. B. Lineas entrecruzadas pintadas dentro de rectángulos en un cuenco hondo (TBO2H10-35). Área 10, Tilbes-Körche. C. Cuenco pequeño (TBo2H10-28). Área H10, Tilbes-Körche. D. Gran cuenco (TBO2H10-19). Área H10, Tilbes-Kórche. E. Cuenco pequeño con triángulos paralelepípedos pintados (TB02H10-8). Área H10, Tilbes-Körche. F. Jarra con asa y decoración pintada (TBO2H10-3). Área H10, Tilbes-Körche. G. Jarra abierta con líneas verticales pintadas entre dos bandas horizontales en el cuello (TBO2H12-6). Área H12, Tilbes-Körche 
The fact of not finding precise parallels for the motifs painted on the Körche or Surtepe ceramics, somehow an individualizing desire typical of Halaf or the first phases of the Ubaid culture persists within the Tilbes-Körche ceramic ensemble. A desire to withdraw from mass productions, despite the persistent repetition in the ceramic or painted repertoire.

Painted bowls are common in Sakçe Gözü up to level IVB, unlike IVC (du Plat Taylor et al., I950). At Yunus, a settlement near ancient Carchemish, in an orographic situation that recalls that of Tilbes-Körche regarding the höyük (Woolley, I934: I46), there are not even exact parallels, either for the shapes or the painted rectilinear or wave patterns (Woolley, 1934: pl. XVIII-XIX), for the ceramics discovered at Tilbes-Körche. The bowl decorated with painted interior decoration (figure Io, middle) from Tilbes-Körche resembles a fragment found in the strata below the NE citadel cut at Carchemish (Wolley, I934: pl. XXI.b.8).

One of the best parallels in the Ubaid tradition painted ceramics and repetitive motifs from Tilbes-Körche is that found in Tell Zeidan Late Ubaid brown painted ceramics (Stein, 2009: fig. 7). But starting both from a common trunk, we see some differences and a tendency to standardize in the unpainted shapes for Tilbes-Körche.

The presence of painted simple plain wares is one of the characteristics of the ceramics painted in LC1 of Tell Kosak Shamali in the Middle Syrian Euphrates (Nishiaki and Matsunati, 2003).

The pottery of the Tilbes-Körche site display other far parallels with like materials from the Khabur river as Tell Kashkashok II, Tell Brak-Uruk fill and Areas CH (Oates, 20I2) and HS (Matthews, 2003), Tell Leilan VI (Schwartz, I988), Northern Irak (Tepe Gawra XII) or the Balih (Tell Hammam et-Turkmann IVD to VA-B). But the Birecik material has a mineral temper and grittier appearance in a good percentage of the bulk (like certain materials from Korucutepe A and earlier B in Upper Euphrates, Brandt, 1973: 440; Van Loon, I978), besides the turning devices used for most of the manufactures of the painted pots ${ }^{4}$. In summary, the anal-

4 Authors as Tsuneki (1992) have stressed the connection during the process of development between the complexity of production and complexity of society. ogies for the unpainted pots in eastern Northern Mesopotamia would fit better in the later phases of Tell Abu Huseini in the Hamrin (Chiocchetti, 2004) or Tell Kashkashuk in the Syrian Khabur (Koziumi, 1993).

Bowls of similar shapes in the Ubaid-like tradition, which appear painted and sometimes unpainted, are usually typical of the Hama sequence (phases L and K) in the Syrian Orontes, and have a chronological range of the Late Ubaid and the beginning of the Late Chalcolithic (Mazzoni, 2000).

Regarding the Khabur materials, if we take Tell Brak as a reference, we see that in the great center of the Khabur there is a significant percentage of bowls and open forms during its LC1-2. Even in mass-produced bowls there is some parallel with the shapes found at Tilbes-Körche. Somehow it resembles both places (Oates, 20I2: fig. 5.55), but in Körche the similar bowls are painted. And on the other hand, we see no parallel between the painted motifs of both places during LC1-2. The painted open bowls, pedestal bowls and jug shapes found on the Tell Brak LC1 levels also bear some kind of parallelism with the Tilbes-Körche ceramic ensemble (Oates, 20I2). However, in Tell Brak, the decorated pottery that appeared in contexts of $\mathrm{LC} 1$ is only $\mathrm{I} \%$ of the total (Oates, 20I2: 7I). It is clear that both regions, Khabur and the main course of the Middle Euphrates, have their differences and cultural influences during the long road of the evolution of the great town at the end of the $5^{\text {th }}$ millennium towards the city of the $4^{\text {th }}$ millennium BC, between the transitions from LC1 to early LC2 phases.

The painted cross-hatched triangles pattern present in the first subphases of LC1 in Tell Feres al Sharqi, also in Khabur basin, later derived (Feres Level $6 a, L C 2)$ in one of the most similar patterns to Tilbes-Körche, the "supporting rectangles" (Baldi, 20I2: pl. 8.4; table 2I). There at Tell Feres, it parallels in time the appearance of bevelled rim bowls.

Grai Resh level V, in the Sinjar of Iraq, is one of the few places where some fragment of painted pottery shows a very close parallel to those found in Tilbes-Körche. These are the triangles with the interior framework and which are supported and delimited in a strip by two lines painted in black (Lloyd, I940: pl. II. fig. 5.35). In the Grai Resh 


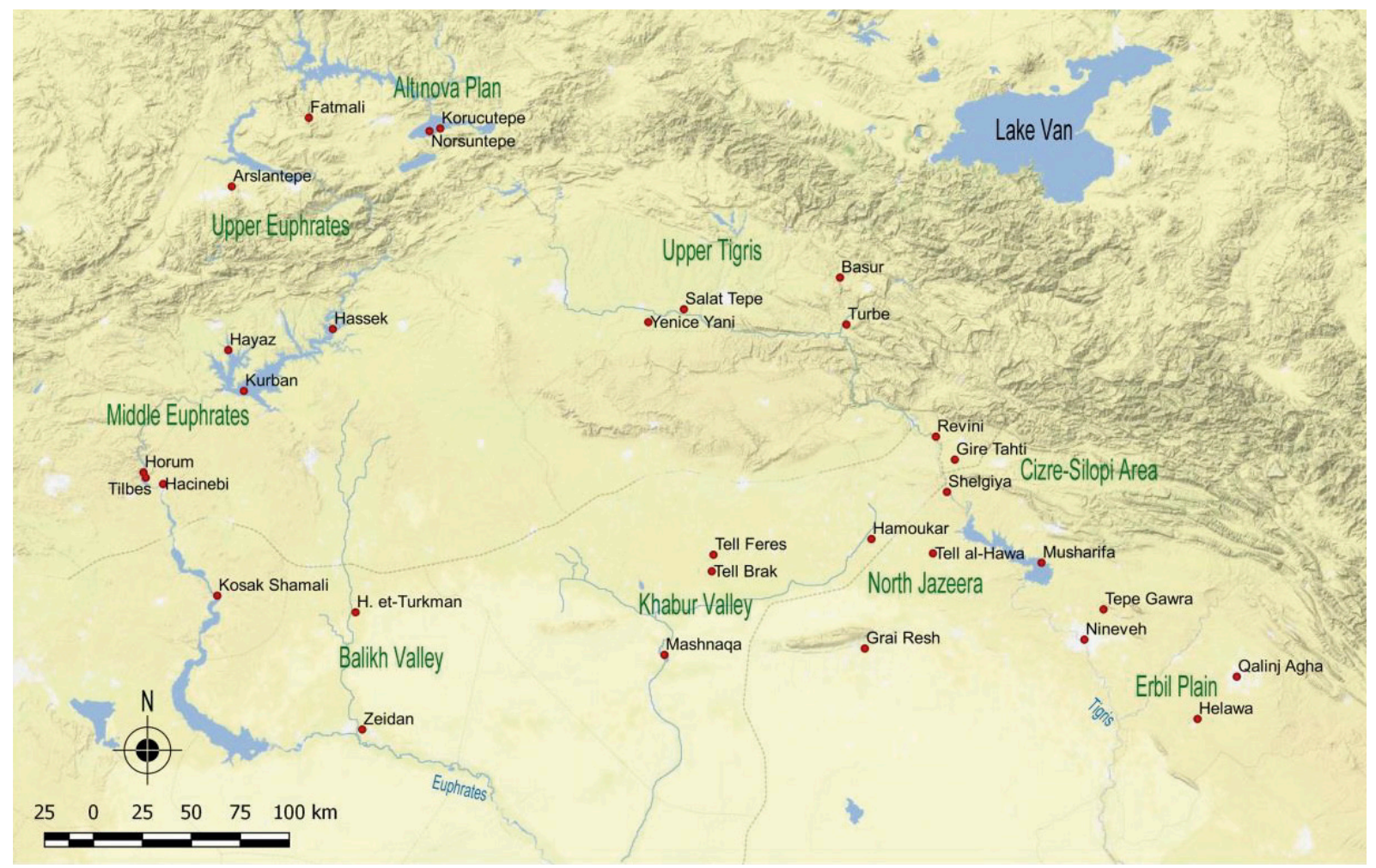

Figure 16. Main Late Chalcolithic 1-2 sites in Northern Mesopotamia (Can, 2018: 113, fig. 3)

Figura 16. Principales asentamientos del Calcolítico Final 1-2 en el norte de Mesopotamia (Can, 2018: 112, fig. 3)

technoceramic ensemble, the percentage of painted ceramics was greater than 60\% (Lloyd, I940: I9). Level V of Grai Resh is the older of the two phases of the site with some elements of Uruk pottery and still shows painted pottery from the Northern Ubaid tradition (Lloyd, I940: 15); would enter within the beginnings of an Ancient Uruk within the chronology of southern Mesopotamia, an LC1 of the North in counterpart.

Most of the technological features of Tilbes-Körche are abundant in Tepe Gawra XII, but the Tepe Gawra technoceramic bulk from its XIII level begins to show some of the characteristics that we also found in the vessels of Tilbes-Körche: good fabrics, monochrome painting, limited ceramic types (here bowls, cups, beakers and jars), decoration in the inside of a bowl, beginning of the ring bases, jars with isolated specimens, a certain presence of green wares (testimonial in Körce); a type of sandy green wares similar to those of Tilbes are found in specific contexts of Tepe Gawra XII (Tobler, I950: 147).

However, Gawra XIII showed for the first time an absence of "halafization" in types and characters, and in addition the beaker dominated the set of vessels there (Tobler, I950: I40). In Tepe Gawra XIII a certain stylistic affinity of its ceramics was also found with Iranian places, but more absent in southern Mesopotamia (Tobler, 1950: 14I). At Tilbes-Körche there are strings cut bowls, and quite a few variants of unpainted bowls. Stamped and incised ware typical of the most advanced moments of LC2 (Oates, 20I2: 73) is totally absent in the whole bulk of Tilbes-Körche, but nevertheless the externally painted and carinated bowls with a similar narrative and anthropomorphic figures are present in Gawra XI-IX (Tobler, 1950: pl. CXLV.398), although the carinated bowl shape is already present in Gawra XII-A and XII (Tobler, I950: pl. LXXIX.f, CXXXIII.235); although the U-shaped profiles associated with the open bowls of Tilbes, with painted patterns that include schematic anthropomorphic figures, look like a variant of "special" U-shaped bowls from the Gawra XIII phase (Tobler, I950: pl. CXXX.203-205), very similar to those of phase "Susa Terminal A" (Alizadeh, 20Io).

The painted motifs of the ceramics from the Gawra XIII levels differ from those found in 
Tilbes-Körche; during the Gawra XII phase, the simple and repetitive motifs typical of many of Tilbes' painted ceramics such as wavy lines and cross-hatched bands (Tobler, 1950: 147) appear, despite the absence of the Gawra triangles (which seem to be replaced in the Birecik sub-region by the Tilbes-Körche rectangles). They have in common their tendency to schematism, and that unlike the Halaf tradition, both places do not show a tendency to a total painting of the containers that are painted. By far, the inherent concepts and some motifs may be coincident, such as triangles or lattices (see Gawra XI-IX, Tobler, 1950: pl. CLII, 518), and even one of the earliest representations of eyepieces painted on northern pottery, such as Gawra XVI-XV (Tobler, 1950: pl. CXLIX, 450).

Analogously, such as in Tilbes-Körche also on the levels of the Acropolis of Susa I in Southwestern Iran (to be dated in the Terminal Ubaid of Mesopotamia), the ceramic pots tend to be open forms, of the bowl type, a certain ceremonial character and an elaborate iconography (Charvat, 2005), which, as in Körche, do not occupy all the ceramic vases. With different representations and symbols, both places of the decline of Ubaid-type culture seem to have a close mindset judging by their use of pottery.

Late Susiana pottery from Choga Mish has some distant echoes also from the Tilbes-Korche set of painted ceramics. In Choga Mish, a vessel (Delougaz, Kantor and Alizadeh, I996: pl. I6o.A) reminds us of a kind of variant of the theme of anthropomorphic figures located between two geometric interweaves. Other specimens (Delougaz, Kantor and Alizadeh, I996: pl. 159.0) show certain parallels due to their lack of "horror vacui" and simple geometric patterns reminiscent of the concept of painted surface in the Birecik specimens.

\section{Conclusions}

Despite the fact that Ubaid is based on Halaf roots in various territories of northern Mesopotamia, the "political" rupture within the villages seems to be greater then, between the Late Ubaid and the post-Ubaid, than later in various areas of the northern Mesopotamia. There seems to be more conflict in southern Mesopotamia territories during the end of phase Ubaid 4 there (Late Ubaid). In any case, if some settlements are abandoned in the area of the main course of the Euphrates (Tilbes Höyuk, Horun Höyuk) and in other nearby ones (Oylum Hoyuk), LC1 there coincides with a fortification after a hiatus (Özgen et al., 1999: 23, fig. 2; Özgen and Helwing, 2003: 64).

We have not an extensive stratigraphic sequence of the Late Ubaid in the Birecik area, despite the evidence of its presence. We cannot know if the Ubaid penetration there was similar to that of adjacent regions. If we are guided by the presence of Late Ubaid-post Ubaid in places on the other side of the border, we see that there is no clear break between the two "periods", but rather gradual changes. We intuited that the Ubaid penetration on the Halaf roots was also gradual in the area. But we do not know if the stylistic peculiarities of the post-Ubaid found in Tilbes-Körche and Surtepe were the result of a late Ubaid local evolution or were the product of external influences.

It is clear that the Late Ubaid culture and its social modes reflected in the architecture managed to penetrate the Birecik-Carchemish area firmly as evidenced by the organization of the architecture excavated in Tilbes-Körche and the arrangement between the two excavated bipartite plants, the discovered tripartite submerged building, and the rest of units. We do not have such similar previous evidence, through excavations of previous periods in the Birecik area, on Neolithic or Halaf settlements.

The interconnected units and buildings of Tilbes-Körche refer us to a large construction arranged in a prepared terrace and controlling a passage of the Euphrates. We can think of a large multi-use building with a certain administrative character, or how, we lean better, a building belonging to the elite and which controlled some of the most important redistributive and productive aspects (stone, bitumen) of the surrounding society.

The placement of bitumen kilns close to, but external to, the "multi-cellular" unit made up of $\mathrm{H}_{3}$-Hio demonstrates a difference still compared to the large urban buildings of the $4^{\text {th }}$ millennium 
where all activities were carried out inside such labyrinthine buildings. Remember that Late Ubaid places like Değirmentepe with its EL, FC and I buildings, or Tell Abada I-II building A still had their home ovens outside the buildings. The appearance of such elements of work outside the edifications may be an archaism in the mental conception of the Tilbes-Körche buildings or a proof that such a settlement has cultural elements more typical of the dawn of LC1 than of its final stage.

Since Late Ubaid there is a packing of structures and buildings in various parts of Mesopotamia, despite local traditions. We can verify in large scale excavated settlements that Degirmentepe (Malatya) has points of similarity with Tell Abada or Tepe Gawra. However, and unlike the accesses to the exterior seen in Degirmentepe, and which reveals the prevailing mentality from the Neolithic of Anatolia in the villages, the Tilbes-Körche architecture shows inputs and outputs from the outside. In Degirmentepe during the Late Ubaid, it was more typical of the construction in blocks, the so-called "agglutinant", with internal accesses, and where the blocks had little access from the outside. The very presence of the stone in the foundations of the Tilbes-Körche structures, absent in the Late Ubaid village of Malatya, reveals another substantial difference. From this point of view, the people from the beginning of the Late Chalcolithic in the Birecik area have embraced the new system, with a different architectural mentality from that prevailing, despite the old roots into the Halaf cultural mentality.

But there is another factor in the mentality of the builders that does make the Tilbes-Körche settlement more typical of an advanced phase of LC1, a certain specialization in the spaces and sectors of the different built units discovered to date in this place of Birecik. Depending on the building or area there is a different functionality, and the built units are no longer multi-functional and integrated in the style of what they were in the Late Ubaid of Northern Mesopotamia.

One of the architectural specimens that, due to their size, most resemble the bipartite and tripartite plants found in Tilbes-Körche, is one of the Tepecik buildings. There earlier Late Chalcolithic (1-2) claimed to be present (Fisher, 20I7: 377-378)
The Tilbes-Körche ceramic ensemble presents a temporal sequence in which there is still a certain predominance of painted ceramics. Based on this, we think that it should be framed within LC1 or a transitional phase between it and LC2. The evidence found in Surtepe Höyük corroborates this presumption.

The number of bowls and cups of various sizes that are present in Tilbes-Körche makes us reflect on the culinary orientation of the inhabitants of the place. An orientation towards eating food very different from that present in the Terminal Halaf or in a good part of Ubaid, where the jugs were more abundant on the archaeological level. Interestingly in Tilbes-Körche certain "halafization" in technique and painted patterns appears on the jars, not on the open bowls.

In Birecik ceramics are not always post-Ubaid-like black-on-buff. Well, there are red paint, Halaf style, but with post-Ubaid motifs. There is a standardization in Tilbes-Korche. These "halafizing" features on some of the Tilbes-Korche LC1 ceramics must respond to a long cultural tradition in Northern Mesopotamia. Recall that in places on the right bank of the Middle Euphrates, not far from Birecik, as in the case of Coba Höyük (du Plat Taylor et al., I950), we find hybridization of elements Halaf and Northern Ubaid in the ceramics of the local Late Ubaid.

Most of the motifs painted on Tilbes-Körche ceramics are repetitive, and tend to be simple (long wavy lines, bands, cross-hatch) but others are somewhat more complex, and tend to be schematic versions of figures. In a way they are equivalent to a representation, painted in series.

We suggest the possibility of crossed influences of Halaf and Ubaid potters during the Terminal Halaf and Late Ubaid times together with a gradual transition to the Ubaid culture, at least in the Carchemish-Birecik sites. As has been interpreted by other researchers (Karsgaard, 2010: 56 ), a fundamental change in the system of social relations occurred since the Late Ubaid, and this is possible to discern through changes in ceramics and the repetition of patterns and shapes. Because the similarities with several painted motifs and after a deep research into the ware, we must place the site 
east of the Tilbes mound in correspondence to the Terminal Ubaid chronology of other regions (local LC1). In such way, these recent Ubaid-like data could clear better the knowledge about the interaction among earlier Late Chalcolithic culture and the painted Ubaid tradition in this region of Northern Mesopotamia.

There is a small set of styling ideas in Tilbes-Korche, which marries certain theories (Stein, 20Io). The transformation of Ubaid ideas as a symbiosis with the Halaf universe, which includes a trend towards standardization and unpainted ceramics. Both cultures still showed traces of a pre-urban society in their political composition where large families or clans weigh on local social control through a series of behaviors or common mindsets, still far from pragmatism and Uruk-type state control.

Regarding the case of some imported green sand paste ceramics in Tilbes-Körche, we check that it is a small percentage of the total bulk; but curiously the almost absolute totality of these greenish pastes belong to bowls or open forms with exclusive motifs of stylized anthropomorphic figures. Ceramic fabric seems imported, but perhaps it was all painted in situ. The paintings on the ceramic containers belong to the same school of painters and pigments as the rest of the containers discovered in our excavations or surveys.

The greenish pastes were already typical of the local Late Ubaid in regions near Northern Mesopotamia, in the neighboring provinces of Gaziantep and Kahramanmaras in southeast Turkey (Campbell and Fletcher, 2010: 72-73). But unlike those pastes, ours from Tilbes Körche are more sandy in appearance, have a slightly grayish coloration and do not show signs of chaff like those specimens of the Ubaid in Domuztepe.

It is striking that despite the evidence, still disparate, in various areas of Mesopotamia or southwestern Iran, on abundant painted ceramics that can be inserted within the chronology of the Late Chalcolithic 1 of the North Tigris and Euphrates, outside the same site hardly exact parallels can be found between the motifs depicted. The omnipresence of the cervid symbol among the objects found in Tilbes during the late Ubaid of the höyük or the local LC1 of Körche refer us to this type of political-social entities common between Birecik, southwestern Iran and other Mesopotamian areas during the period. The ceramic shapes of Susa I seem to be concentrated in two types, open bowls without decoration or painted with partial decoration on their surface, and closed jugs or jars with greater decorated surface, when painted. In other words, two types of recipients associated with the idea of distribution and storage. Such as Tilbes-Körche site; and as in the place in the southeast of Turkey, the high percentage of painted ceramics (Steve and Gasche, 1990) would associate the settlement of the Acropolis of Susa I with a society based on the weight of individual characters, an elite, family or clan, controlling the vital and economic aspects of pre-urban society.

Evidence of a strong "individualistic" mindset, with dispersed socio-political power based on kinship ties or family or clan loyalty, rooted in $\mathrm{Ha}-$ laf-Ubaid cultures. It is a feature against the corporate mentality more present in the "plain simple chaff-faced" or Uruk cultures since LC3 phase onwards. Although such a process of social differentiation began in other regions of Mesopotamia centuries before. Perhaps portions of the Northern Euphrates maintained that archaic clan-based mindset much longer than others; which would explain the absence of an early Uruk in some sub-regions, such as that of Carchemish-Birecik, during LC2, as we can see in Hacinebi A, still with local powers.

We verified there by the number of bowls serial produced, by hand or mold-made, that a world less attached to the local past and more in line with certain pragmatic ideas originating in the South?, or rather a local one that tried to emulate the achievements of the South and began to stand out, in view of the growing dominance of chaff-tempered, plain simple ceramics appearing in northern Mesopotamia in phases such as Hammam et-Turkman IVC or Tell-'Abr IV. Seen in this way, the appearance of Coba bowls during the Late Ubaid was not a mere fad, nor an experiment, but the certification that some social and economic practices began to replace older ones. 
Coba bowls seem to be older in certain regions of Northern Mesopotamia, i.e. North-Western Tigris area (and considering it one of the possible nuclear regions for this kind of vessel). Soundings $\mathrm{C}_{1}$ and $\mathrm{C}_{2}$ of Surtepe Höyük showed that at least in this great settlement of the Late Ubaid there were traditional Coba bowls. If those pots appear so early in the sequence of Middle-Upper Euphrates (e.g. Surtepe) is because these areas could be related or in contact with them. The absence of the Coba types (e.g. Tepe Gawra) or later appearance in other regions (as Southern Mesopotamia or in the Hamrin) perhaps could be because a lack of regular direct relationship between the regions in question.

The presence of various variants of LC1 flint scraped or mass-produced bowls along the Euphrates, such as Tilbes-Körche or the höyük of Tilbes, and other regions of Mesopotamia further East suggests some kind of influence of the "fashions" still coming from the Late Ubaid stage in northern Mesopotamia; and that it is in spite of not having a very evident rupture in the cultural plane, if certain gradual changes are evident in LC1, as if political control had changed axis.

It is interesting that the two bowls that most resemble the so-called "flower pots" typical of the LC1/2 phase appear concentrated in a specific area of Tilbes-Körche, Hio (figures I2 and I5c). Which will have some kind of connection with the distribution of a type of food product.

We do not have clear the final date of the Late Ubaid at Surtepe because there is no apparent abandonment between the Late Ubaid and the Late Calcolithic 1 and early LC2, according to the Area C soundings. Although in EI there is a clear flood like in the Tilbes' höyük. Also, the layers of LC3-4 are direct on those of LC1-2. We were unable to excavate after 2010 and obtain information about it. It is one of the goals to carry out in future excavation campaigns.

We see that at the end of the Late Ubaid in Tilbes Höyük there was a severe flooding, occurred at some point during or immediately after its local occupation Late Ubaid. We think about climate change at the end of the $5^{\text {th }}$ millennium or at the dawn of the $4^{\text {th }}$ millennium as a possible explanation. Tilbes Höyük was abandoned to occupy during $\mathrm{LC} 1$ a large area outside of the former tells at Tilbes-Körche, by a large population judging by the square meters excavated or the area surveyed. The best explanation we find is that some höyüks were abandoned for a certain time due to flooding; is a proven point in Tilbes Höyük, being at a lower altitude, and the concentration of activities of its former population in nearby points but higher than the river level.

Our impression based on the excavations, soundings or surveys of the Tilbes Project is that in Tilbes-Körche we are facing a moment immediately after the Late Ubaid found in Tilbes Höyük or Surtepe. There does not appear to be a cultural break in the Ubaid tradition of pottery just as LC begins in the Birecik area. We might think that the population of Tilbes-Körche during the settlement were the descendants of those who were in the höyük of Tilbes in the Late Ubaid and some earlier phase of the LC1.

It seems that after the Late Ubaid, a profound change in the political and social dominance of certain "villages" in northern Mesopotamia during LC1-Early LC2 is unclear. They appear to have similar organization patterns. At least there seems to be a certain northern koiné from LC1-2 of northern Mesopotamia. If the exchange networks changed since the Late Ubaid we still do not know it deeply in the region, but the economy of the Birecik LC1-2 seems to follow the lines of continuity of other areas of Mesopotamia between the Late Ubaid and the Terminal phases. An economy where bitumen is important, perhaps more than metal in the Birecik-Carchemish area. Lithic technology and stones presence were very important in Tilbes Höyük and Körche. Continuity in obsidian traffic from eastern Anatolia has been verified with contact networks between hundreds of kilometers away, at least using the artery of the Euphrates River and its tributaries.

The end of Tilbes-Körche does not seem to be due to a conflict at the end of the $5^{\text {th }}$ millennium, ca. $4200 \mathrm{BC}$, according to recent calibrated dates, such as those of Tell Zeidan. Perhaps the post-Ubaid (LC1) in the Birecik area and in nearby subregions 
of the Euphrates experienced a transformation of the Ubaid culture, which led to a gradual decline of its social and economic system which is what we contemplate in the abandonment of Tilbes-Körche and the reoccupation during Late Chalcolithic 2 of central nodes as Surtepe or new sites as the fortified settlement of Hacinebi.

\section{Bibliography}

Abu Jayyab Kh. (20I2): "A ceramic chronology from Tell Hamoukar's southern extension”. In C. Marro (ed.): After the Ubaid. Interpreting change from the Caucasus to Mesopotamia at the dawn of urban civilization (4500-3500 BC) (Fosseuse, 2009). Varia Anatolica, 27. Institut Français d'Études Anatoliennes-Georges Dumézil. Istanbul: 87-I27. Akkermans, P.M.M.G. (1988): "An Updated Chronology for the Northern Ubaid and Late Chalcolithic Periods in Syria: New evidence from Tell Hammam at-Turkmann". Iraq, 50: 109-I45. https://doi.org/IO.2307/4200288

Alizadeh,A. (20Iо): "The Rise of the Highland Elamite State in Southwestern Iran 'Enclosed' or Enclosing Nomadism?”. Current Anthropology, 5I (3):353-383. https://doi.org/ro.Io86/652437

Baldi J.S. (2OI2): "Tell Feres al-Sharqi in the $\mathrm{LC}_{\mathrm{I}-2}$ period. Serial production and regionalisation of ceramic traditions: a perspective from a small rural site". In C.Marro (ed.): After the Ubaid. Interpreting change from the Caucasus to Mesopotamia at the dawn of urban civilization (4500-3500 BC) (Fosseuse, 2009). Varia Anatolica, 27. Institut Français d'Études Anatoliennes-Georges Dumézil. Istanbul: I29-16I.

Ball, W. (1997): “Tell Shelgiyya: An Early Uruk 'Sprig Ware'Manufacturing and Exporting Centre on the Tigris". Al-Rafidan, I8: 93-I04.

Blackham, M. (1996): "Further investigations as to the relationship of Samarran and Ubaid ceramic assemblages". Iraq, 58: I-I6. https://doi. org/Io.IOI7/Soo21088900003144

\section{Acknowledgements}

During the preparation of this article, various suggestions were mentioned by Eduardo A. Crivelli. We must thank the collaboration provided during the making of the original field drawings by Ben C. Coockson and Rafael Moya Molina, the pencil pottery drawing by R. Moya and the pottery digitalization by Carmen Ana Pardo Barrionuevo.

Braidwood, R.J., Braidwood, L.S. and Haines, R.C. (1971): Excavations in the Plain of Antioch. University of Chicago Oriental Institute publications, 6r. University of Chicago Press. Chicago.

Brandt, R.W. (1973): "The Excavations at Korucutepe, Turkey, 1968-70: Preliminary Report. Part IV: The Chalcolithic Pottery". Journal of Near Eastern Studies,32 (4): 439-444. https://doi.org/ro.Io86/372299

Breniquet, C. (1995): "La stratigraphie des niveaux préhistoriques de Mersin et l'evolution culturelle en Cilicie". Anatolia Antiqua, 3: I-31.

Bronk Ramsey, C. (2009): "Bayesian Analysis of Radiocarbon dating". Radiocarbon, 5I (I):337-360.

Bronk Ramsey, C. (20I7): OxCal software version 4.3.2. https://ci4.arch.ox.ac.uk/oxcal.html

Brustolon, A. and Rova E. (2007): "The Late Chalcolithic Period in the Tell Leilan Region: A Report on the Ceramic Material of the 1995 Survey". Kaskal. Rivista di storia, ambienti e culture del Vicino Oriente Antico, 4: I-42.

Campbell, S. and Carter, E. (1999): "Excavations at Domuz Tepe 1997". 20 Kazi Sonuclari Toplantisi (Tarsus, 1998). I. Ankara: 283-294.

Campbell, S. and Fletcher. A. (2010): "Questioning the Halaf-Ubaid Transition”. In R.A. Carter and G. Philip (eds.): Beyond the Ubaid:transformation and integration in the late prehistoric societies of the Middle East (Durham, 2006). Studies in Ancient Oriental Civilization, 63. Oriental Institute of the University of Chicago. Chicago, Ill.: 69-83.

Can, Ş. (2018): Continuity and Change: An Annales approach to the Late Chalcolithic to the Late Chalcolithic period in North Mesopotamia. Master's Thesis. Department of Archaeology. İhsan Doğramac1 Bilkent University. Ankara. 
Charvát, P. (2005): The Iconography of Pristine Statehood: Painted Pottery and Seal Impressions from Susa, Southwestern Iran. Charles University in Prague. Karolinum Press. Prague.

Chiocchetti, L. (2004): "Hamrin-Tell Abu Husseini. La ceramica tardo-obeid dei livelli I-3”. Mesopotamia, 39: I-70.

Contenson, H. de (1963): "New correlations between Ras Shamra and Al-'Amuq". Bulletin of the American Schools of Oriental Research, I72: 35-40.

Contenson, H. de (1973): "Le niveau halafienne de Ras Shamra”. Syria, 50: 13-33.

Contenson, H. de (1982): "Les phases préhistoriques de Ras Shamra et de l'Amuq". Paléorient, 8: 95-98.

Copeland, L. (1979): "Observations on the Prehistory of the Balikh Valley, Syria, during the $7^{\text {th }}$ to $4^{\text {th }}$ Millennia B.C.”. Paleorient, 5: 251-275.

Crivelli,E. and Gil Fuensanta,J.(2008): "Observaciones sobre la tecnología lítica de Surtepé (alto Éufrates) en el Calcolítico Final/Edad del Bronce". III Congreso Nacional de Arqueología Histórica (Rosario, Argentina, 2006): Universidad Nacional de Rosario. Rosario: 24I-249.

Croucher, K. (20I0): "Figuring out Identity: The Body and Identity in the Ubaid". In R.A. Carter and G. Philip (eds.): Beyond the Ubaid: transformation and integration in the late prehistoric societies of the Middle East (Durham, 2006). Studies in Ancient Oriental Civilization, 63. Oriental Institute of the University of Chicago. Chicago, Ill.: II3-I23.

Delougaz, P., Kantor H. and Alizadeh, A. (1996): Choga Mish. Vols. I-2. The First Five Seasons of Excavations, I96r-197r. Oriental Institute Publications ror. Chicago University Press. Chicago.

Egami, N.(ed.) (1958): Telul et-Thalathat, volume r: The Excavation of Tell II: The First and second Season (1956-1957). Tokyo University-Iraq Archaeological Expedition Report r. Tokyo Institute of Oriental Culture. Tokyo.

Esin, U. (1994): "The Functional evidence of Seals and Sealings of Degirmentepe". In P.Ferioli, E. Fiandra, G.G. Fissore and M. Frangipane (eds.): Archives Before writing (Oriolo Romano, I991). Rome: 59-82. Fisher, M.T. (20I7): The Late Chalcolithic I Period in Northern Mesopotamia: Tell Zeidan, Syria, in Regional Context. Dissertation. University of Chicago. Chicago.
Forest, J.D. (1996): Mésopotamie. L'apparition de l'État. Ve-IIIe millénaires. Grandes civilisations. Jaca Book \& Paris-Méditerranée. Milan-Paris. Fukai, S., Horiuchi, K. and Matsutani, T. (1970): Telul eth-Thalathat, Vol. II, The Excavations of Tell II, The Third Season (1964). Tokyo Institute of Oriental Culture. The University of Tokyo-Yamakawa Pub. Tokyo.

Giannessi D. (2012): "Tell Afis and the northern Orontes region in the Post-Ubaid period". In C. Marro (ed.): After the Ubaid. Interpreting change from the Caucasus to Mesopotamia at the dawn of urban civilization (4500-3500 BC) (Fosseuse, 2009). Varia Anatolica, 27. Institut Français d'Études Anatoliennes-Georges Dumézil. Istanbul: 26I-289. Gil Fuensanta, J. and Misir, A. (1998): "Excavations at Tilbes Höyük: The 1996 Season”. XIX Kazı Sonuçlari Toplantisi. I. Anttlar ve Muzeler Genel Müdürlüğü Yayınları. Ankara: 227-243.

Hammade,H. and Koike, Y.(1993): "Some Remarks on the Uruk Levels at Tell al-'Abr on the Euphrates". Akkadica 84-85: 53-62.

Hammade, H. and Yamazaki, Y. (2006): Tell Al-'Abr (Syria): Ubaid and Uruk Periods. Association Pour la Promotion de l'Histoire et de l'Archéologie Orientales Memo-Peeters. Leuven.

Hole, F.(I990): "Cemetery or Mass Grave? Reflections on Susa I'. In F.Vallat (éd.): Contribution à l' histoire de l'Iran. Mélanges offerts à Jean Perrot. Éditions Recherche sur les Civilisations. Paris: I-I4.

Hole, F. (1994): "Environmental Instabilities and Urban Origins". In G. Stein and M. Rothman (eds.): Chiefdoms and Early states in the Near East. Monographs in World Archaeology, i8. Prehistory Press. Madison-Wiscosin: I2I-I5I.

Henrickson, E.F. and Thuesen, I. (eds.) (1988): Upon this Foundation. Museum Tusculanum Press/Carsten Niebuhr Institute. Copenhagen.

Jasim, S.A. (1985): The 'Ubaid Period in Iraq. Recent Excavations in the Hamrin Region. British Archaeological Reports International Series, 267. Oxford.

Jasim, S.A. and Oates, J. (1986): "Early tokens and tablets in Mesopotamia: new information from Tell Abada and Tell Brak". World Archaeology, r7: 348-36r. 
Johnson, G.A. (1988-89): "Late Uruk in Greater Mesopotamia: Expansion or Collapse?”. Origini, I4: 595-6i3.

Karsgaard, P. (2010): "The Halaf-Ubaid Transition: A Transformation without a Center?". In R.A. Carter and G. Philip (eds.): Beyond the Ubaid: transformation and integration in the late prehistoric societies of the Middle East (Durham, 2006). Studies in Ancient Oriental Civilization, 63. Oriental Institute of the University of Chicago. Chicago, Ill.: 5I-67.

Kozbe, G. and Rothman, M.S. (2005): "Chronology and Function at Yarim Höyük, Part II”. Anatolica, 3I: III-I44.

Koziumi, T. (1993): "Ubaid pottery from Kashkashok II: Typology and chronology". Al-Rafidan, I4: 19-67.

Lebeau, M. (1983): "Les objects du niveau Obeid 4 de Tell el 'Oueili: Rapport préliminaire”. In J.L. Huot (ed.): Larsa et Oueili, travaux de 1978-I98I, rapport préliminaire. Editions Recherche sur les Civilisations Mémoire, 26. Paris.

Lloyd, S.(1940): "Iraq Government Soundings at Sinjar". Iraq, 7: I3-2I. https://doi.org/ro.2307/4241662

Marro, C., Tibet A. and Ergeç, R. (1999): "Fouilles de Sauvetage de Horum Höyük (Province de Gaziantep): Troiseme Rapport Preliminaire”. Anatolia Antiqua, 7: 349-378.

Matsutani, T. (ed.) (1991): Tell Kashkashok, the Excavations at Tell No. II. University of Tokyo Press. Tokyo.

Matthews, R. (2003): Excavations at Tell Brak. Vol. 4, Exploring an Upper Mesopotamian Regional Center, I994-1996. McDonald Institute for Archaeological Research. Cambridge.

Mazzoni S. (2000): "From the Late Chalcolithic to Early Bronze I in North-West Syria: Anatolian contact and regional perspective". In C. Marro and H. Hauptmann (eds.): Chronologies des pays du Caucase et de l'Euphrate aux IVe-III millénaires. From the Euphrates to the Caucasus (Istanbul, 1998). Institut Français d'Études Anatoliennes Georges Dumézil. Varia Anatolica, Ir. Istanbul: 97-II4.
Mühl, S. and Nieuwenhuyse, O.P. (20I6): "Halaf and Ubaid period settlement: a view from the Central Zagros Piedmont". In M. Iamoni (ed.): Trajectories of Complexity. Socio-economic Dynamics in Upper Mesopotamia in the Neolithic and Chalcolitbic Periods. Studia Chaburensia, 6. Wiesbaden: 27-56.

Nishiaki, Y. and Matsutani, T. (eds.) (20or): Tell Kosak Shamali Vol. I. The Archaeological Investigations in the Upper Euphrates, Syria. Chalcolithic Architecture and the Earlier Prehistoric Remains. UMUT Monograph I. Oxbow books/The University Museum. The University of Tokyo. Tokyo-Oxford.

Nishiaki, Y. and Matsutani, T. (eds.) (2003): Tell Kosak Shamali: The Archaeological Investigations on the Upper Euphrates, Syria, Volume 2: Chalcolithic Technology and Subsistence. Oxbow Books. Tokyo-Oxford.

Munchaev, R.M. and Merpert, N.Y. (198I): Rannezemledel'chekiye poseleniya severnoy Mesopotamii. Moscow.

Munchaev, R.M. (1997): "The Halaf culture: Peculiarities of the V Mil. B.C. North Mesopotamian Architecture”. Al-Râfidân, I8: 69-79.

Oates, J. (1976): "Prehistory in Northeastern Arabia". Antiquity, 50: 20-3r. https://doi.org/Io.Ior7/ Sooo3598Xooo70599

Oates, J. (1994): “Tell Brak: A Stratigraphic Summary, 1976-1993”. Iraq, 56: 167-176. https://doi. org/10.1017/Soo21088900002916

Oates, J. (20I2): "The Terminal Ubaid (LCI) Level at Tell Brak". In C. Marro (ed.): After the Ubaid. Interpreting change from the Caucasus to Mesopotamia at the dawn of urban civilization (4500-3500 BC) (Fosseuse, 2009). Varia Anatolica, 27. Institut Français d'Études Anatoliennes-Georges Dumézil. Istanbul: 65-86.

Özbal. H. and Turan, Ü (2002): “Tilbeş Höyük ve Surtepe: M.Ö. 3. Biny1lda Güneydoğu Anadolu Metalurjisi”. I7 Arkeometri Sonuçlari Toplantisi. Anıtlar ve Muzeler Genel Müdürlüğü Yayınları. Ankara: 59-70

Özgen, E. and Helwing, B. (2003): "On the shifting border between Mesopotamia and the west: Seven seasons of joint Turkish-German excavations at Oylum Höyük”. Anatolica, 29: 6I-85. 
Özgen, E.; Helwing, B.; Engin, A.; Niewenhuyse, O. and Spoor, R. (1999): "Oylum Höyük 1997-1998. Die Spätchalkolitische Siedlung auf der Westterrasse". Anatolia Antiqua, 7: 19-67.

Parker, B.J. and Kennedy J.R. (20ro): "A Quantitative Attribute Analysis of the Ubaid-Period Ceramic Corpus from Kenan Tepe". Bulletin of the American Schools of Oriental Research, 358: I-26. https:// doi.org/ro.1086/basor25741804

Perkins, A.L. (1977): The Comparative Archaeology of Early Mesopotamia. Oriental Institute Publications. Studies in Ancient Oriental Civilization, $25 \cdot 7^{\text {th }}$ edition. Chicago, Ill.

Peyronel, L., Vacca, A. and Zenoni, G. (2016) "Helawa: A New Northern Ubaid/Late Chalcolithic Site in the Erbil Plain". In K. Kopanias and J.MacGinnis (eds): Archaeological Research in the Kurdistan Region of Iraq and the adjacent areas (Athens, 2013). Archaeopress Archaeology. Oxford: 309-32I.

Pittman, H. (1999): "Administrative Evidence from Hacinebi Tepe: an Essay on the Local and the Colonial”. En G. Stein (ed.): The Uruk expansion: Northern perspectives from Hacinebi, Hassek höyük et Gawra. Paléorient, 25 (I): 43-50.

Plat Taylor,J.du; Seton-Williams, M.V. and Waetcher,J. (1950): “The Excavations at Sakçe Gözü”. Iraq, I2 (2): 53-I38. https://doi.org/Io.2307/424I706

Reimer, P.; Austin, W.E.N.; Bard, E.; Bayliss, A.; Blackwell, P.G.; Bronk Ramsey, C.; Butzin, M.; Edwards, R.L.; Friedrich, M.; Grootes, P.M.; Guilderson, T.P.; Hajda, I.; Heaton, T.J.; Hogg, A.; Kromer, B.; Manning, S.W.; Muscheler, R.; Palmer,J.G.; Pearson, C.; van der Plicht,J.; Reim Richards, D.A.; Scott, E.M.; Southon, J.R.; Turney, C.S.M.; Wacker, L.; Adolphi, F.; Büntgen, U.; Fahrni, S.; Fogtmann-Schulz, A.; Friedrich, R.; Köhler, P.; Kudsk, S.; Miyake, F.; Olsen, J.; Sakamoto, M.; Sookdeo, A. y Talamo, S. (2020): "IntCal2o Northern Hemisphere radiocarbon age calibration curve (o-55 cal kBP)". Radiocarbon, 62: I-33. https://doi.org/ro.IoI7/RDC.2020.4I

Rothman, M.S. (ed.) (200I): Uruk Mesopotamia and Its Neighbors. Cross-Cultural Interactions in the Era of State Formation. School of American Research Advanced Seminar Series. Santa Fe.
Sanlaiville, P. (ed.) (1985): Holocene Settlement in North Syria. Résultats de deux prospections archéologiques effectuées dans la région du Nabr Sajour et sur le haut Euphrat syrien. British Archaeological Reports, international Series, 238. Oxford.

Schwartz, G. (1988): A Ceramic Chronology from Tell Leilan: Operation I. Yale Tell Leilan Research, vol. I. Yale University Press. New Haven-London.

Schwartz, G. and Hollander (2008): "Bulk stable carbon and deuterium isotope analyses of bitumen artifacts from Hacinebi Tepe, Turkey: reconstructing broad economic patterns of the Uruk expansion". Journal of Archaeological Science, 35: 3I44-3158. https://doi.org/Io.IoI6/j.jas.2008.06.02I

Schwartz M., Hollander D. and Stein G.J. (1999): "Reconstructing Mesopotamian Exchange Networks in the $4^{\text {th }}$ Millennium BC: Geochemical and Archaeological Analyses of Bitumen Artifacts from Hacinebi Tepe, Turkey". In G. Stein (ed.): The Uruk expansion: Northern perspectives from Hacinebi, Hassek höyük et Gawra. Paléorient, 25 (I): 67-82.

Speiser, E.A. (1935): Excavations at Tepe Gawra, vol. I: Levels I-VIII. University of Pennsylvania Press. Philadelphia.

Stein, G. (1994): "Economy, Ritual, and Power in 'Ubaid Mesopotamia”. In G. Stein y M. Rothman (eds.): Chiefdoms and Early states in the Near East. Monographs in World Archaeology, i8. Prehistory Press. Madison-Wisconsin: 35-46.

Stein, G. and Misir, A. (1995): "I994 Excavations at Hacinebi Tepe”. XVII Kazi Sonuclari Toplantisi (1995). I. Ankara: I09-I28.

Stein, G. (1999): "I997 Excavations at Hacinebi". XX Kazi Sonuclari Toplantisi (Tarsus, I998). I. Ankara: 183-203.

Stein, G. (2009): “Tell Zeidan [2008]". Oriental Institute Annual Report, 2008-2009: I26-I37.

Stein, G. (2oroa): "Local identities and interaction spheres: modeling regional variation in the Ubaid horizon". In R.A. Carter and G. Philip (eds.): Beyond the Ubaid: transformation and integration in the late prehistoric societies of the Middle East (Durham, 2006). Studies in Ancient Oriental Civilization, 63. Oriental Institute of the University of Chicago. Chicago, Ill.: 23-44. 
Stein, G. (20Iob): “Tell Zeidan. 2009 Excavations and Laboratory Works". Oriental Institute Annual Report, 2009-2010: 105-II8.

Stein, G. (20II): “Tell Zeidan. 2oro Field Work". Oriental Institute Annual Report, 2010-201г: I2I-I38.

Stein, G. (20I2): “The Development of Indigenous Social Complexity in Late Chalcolithic Upper Mesopotamia in the $5^{\text {th }}-4^{\text {th }}$ Millennia BC-An Initial Assessment”. Origini, 34: I25-I5I.

Stein, G.J. (20I4): "Economic dominance, conquest, or interaction among equals? Theoretical models for understanding culture contact in early Near Eastern complex societies". In M.H. Azizi Kharanaghi, M. Khanipour and R. Naseri (eds.): International Congress of Young Archaeologists (Tehran, 20I4). University of Tehran Press. Tehran: $55^{-6}$.

Steve M.-J. and Gasche H. (1990): "Le tell de l'Apadana avant les Achéménides: contribution à la topographie de Suse". In F. Vallat (ed.): Contribution à l'bistoire de l'Iran. Mélanges offerts à Jean Perrot. Editions Recherche sur les Civilisations. Paris: $15-60$.

Stuiver, M.; Reimer, P.J.; Bard, E.; Beck,J.W.; Burr, G.S.; Hughen, K.A.; Kromer, B.; McCormac, G.; Plicht,J.van der y Spurk, M. (1998): "Intcal98 radiocarbon age calibration, 24.000-0 cal BP". Radiocarbon, 40 (3): I04I-1083.

Tobler, A. (1950): Excavations at Tepe Gawra, vol.2. University of Pennsylvannia Press. Philadelphia. Tsuneki, A. (1992): "Pottery Neolithic to Ubaid related periods in the Rouj Basin" (in japanese). En T. Iwasaki y H. Nishino (eds.): An Archaeological Study on the development of Civilization in Syria. Institute of History and Anthropology, University of Tsukuba. Tsukuba: 82-89.
Van Loon, M.N. (1978): Korucutepe: Final Report on the Excavations of the Universities of Chicago, California (Los Angeles) and Amsterdam in the Keban Reservoir, Eastern Anatolia, 1968-1970. North-Holland Pub. Co. Amsterdam.

Watson, P.J. (1983): "The Soundings at Banahilk". In L.S. Braidwood, L.S. Braidwood, B. Howe, C.A. Reed and P.J. Watson (eds.): Prehistoric Archaeology along the Zagros Flanks. Oriental Institute Publications, 105. The Oriental Institute. Chicago, Ill.: 545-6r3.

Woolley, C.L. (1934): "The Prehistoric Pottery of Carchemish”. Iraq, I (2): I46-I62. https://doi. org/10.2307/4241569

Wilkinson, T.J. (1990): "The development of settlement in the North Jazira between the 7 th and ist Millennia B.C.”. Iraq, 52: 49-62. https://doi. org/ $/ 0.2307 / 4200318$

Wilkinson, T.J.; Galiatsatos, N.; Lawrence, D.; Ricci, A.; Dunford, R. and Philip, G. (2012): "Late Chalcolithic and Early Bronze Age Landscapes of Settlement and Mobility in the Middle Euphrates: A Reassessment". Levant, 44 (2): 139-185. http://dx. doi.org/Io.II79/0075891412Z.0000000007

Wright, H.T. and Rupley, E.S.A. (200I): "Calibrated Radiocarbon Age Determinations of Uruk-Related Assemblages”. In M.S. Rothman (ed.): Uruk Mesopotamia and Its Neighbors. Cross-Cultural Interactions in the Era of State Formation. School of American Research Advanced Seminar Series. Santa Fe: 85-122.

Yamazaki, Y. (2000): "Excavations at Tell al-'Abr". In G. del Olmo and J.L. Montero Fenollos (eds.): Euphrates. The Tishrin Dam Area (Barcelona, 1998). Aula Orientalis Supplementa. Ausa. Sabadell-Barcelona: 83-96. 